The Journal of Mesopotamian Studies

ISSN:2147-6659 / e-ISSN: 2687-6388

Demir, i. (2021). ابن الحاجب: حياته و آثاره العلمية و الفكرية , The Journal of Mesopotamian Studies, 6 (1),

157-172 DOI: 10.35859/jms.2021.831033.

\section{MAKALE BILGISI/ARTICLE INFO}

Article Type/Makale Türü: Research Article / Araştirma Makalesi

Received / Makale Geliş Tarihi: 14.01.2021

Accepted / Makale Kabul Tarihi: 17.02.2021

Doi: $10.35859 /$ jms.2021.861020

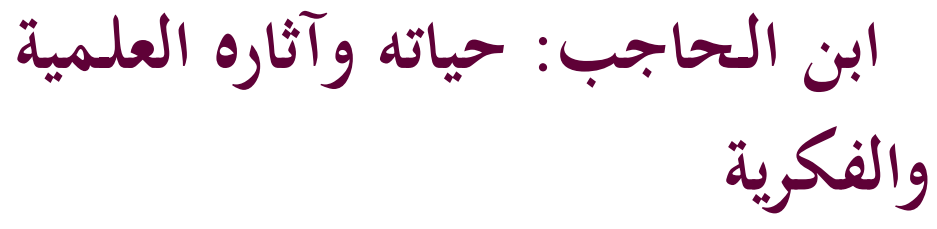

İbnü'l-Hacib: Hayat, Eserleri ve Entelektüel Yönü
PhD Candidate, University of Abou Bekr Belkaid, Arabic Language and Literature. Tlemcen, Algeria.

ecmeldemirr@hotmail.com,

https://orcid.org/0000-0003-2529-3746

İsmail Demir

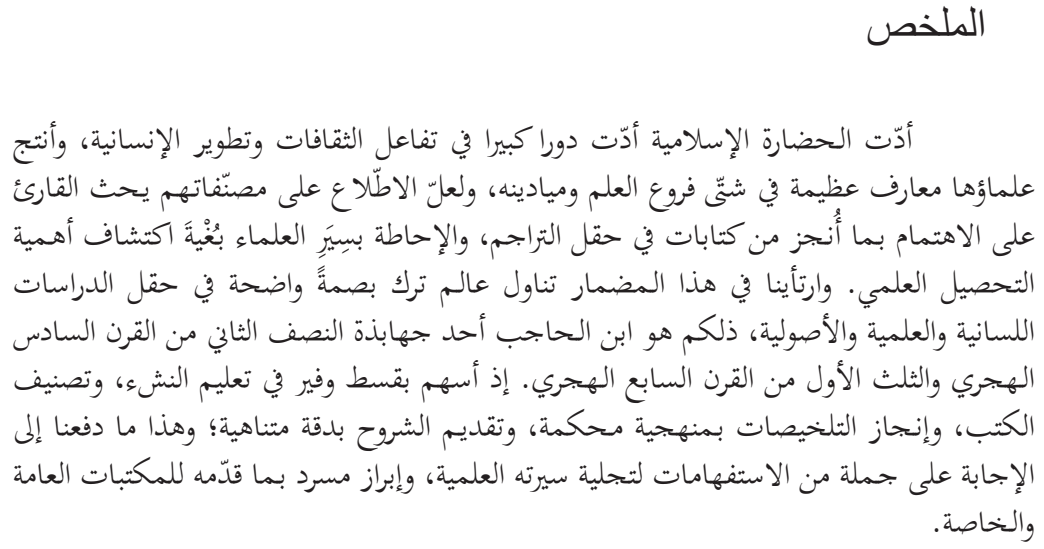

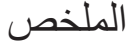

أدّت الحضارة الإسلامية أدّت دورا كبيرا في تفاعل الثقافات وتطوير الإنسانية، وأنتج

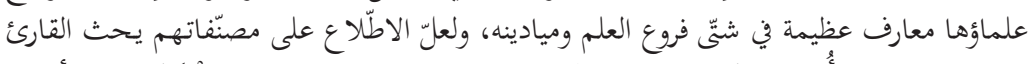

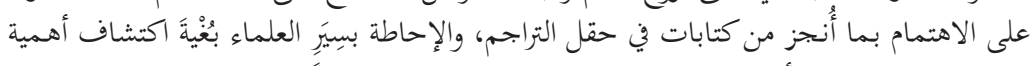

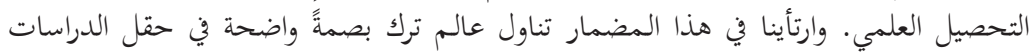

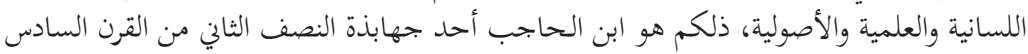

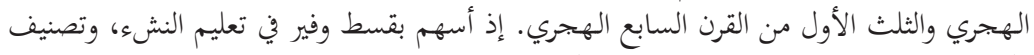

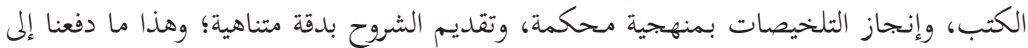

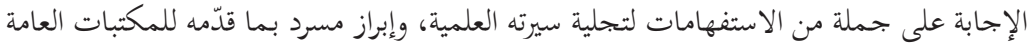
والخاصة.

كلمات مفتاحية: ابن الحاجب، علم النحو، الكافية، الثافية. 


\title{
İbnü'l-Hacib: Hayatı, Eserleri ve Entelektüel Yönü
}

\section{ÖZ}

İslam medeniyeti, kültürlerin etkileşmesinde ve insanlığın gelişmesinde büyük rol oynamıştır. İslam âlimleri bilimin çeşitli dallarında ve alanlarında büyük akademisyenler yetiştirmişlerdir. Böylece onların teliflerini anlamak, okuyucuyu çeviri alanında yapılan eserlere çekmek ve de eğitimde başarının önemini keşfetmek için âlimlerin biyografilerini bilmek teşvik edilmiştir. Biz, burada bu alanda Hicri altıncı yüz yılın ikinci yarısı ile yedinci yüz yılın başlarında dil bilimi ve yöntemi alanında köklü araştırmalarıyla açık bir iz bırakan, gençlerin eğitimine, kitapların sınıflandırılmasına, özetlerin sıkı bir metodoloji ile tamamlanmasına ve ilave açıklamalarını son derece doğru bir şekilde sunmasına büyük katkıda bulunan İbn el-Hâcib'i inceleyeceğiz. Bizi bu makalede bir dizi soruyu yanıtlamaya iten, onun genel ve özel eserlerinin özetini ortaya koymak ve bilimsel kariyerini açıklığa çıkartmak olmuştur.

Anahtar Kelimeler: İbnü’l-Hâcib, Nahiv ilmi, el-Kâfiye, eş-Şâfiye.

\section{Ibn Hajeeb: His Life, Works and Intellectual Aspect}

\begin{abstract}
The Islamic civilization played a major role in developing humanity. Its scientists produced great knowledge in different fields and branches of science. To understand their works, to stimulate the readers to investigate translated works, and to discover the significance of achievement in education, it is encouraged to know the biographies of scholars. This article deals with one of the characters who left a print in the field of linguistic, scientific and fundamental in teaching generations and played a role in enriching the Islamic library and scientific centers; Ibn Hajeeb. We will try to identify his scientific career defining his scientific activities and uncovering his pieces of writing.
\end{abstract}

Keywords: Ibn al-Hajeeb, Grammar, al-Kâfiya, al-Shâfiya.

\section{Extended Summary}

In this study we saw a scholar who left a clear imprint in the field of linguistic, scientific and fundamentalist studies. This is Ibn Hajeeb, one of the scholars of the second half of the sixth century AH and the first third of the seventh century AH. He contributed abundantly to the education of young people, classifying books, completing summaries in a tight methodology, and presenting explanations with extreme accuracy. This is what prompted us to answer a number of inquiries to illustrate his scientific career, and to highlight a glossary of what he presented to public and private libraries.

The Islamic civilization has played a great role in the interaction of cultures and the development of humanity, and its scholars have produced great knowledge in various branches and fields of science, and looking at their works may encourage the reader to pay attention to the writings that have been accomplished in the field of translations, and to take note of the biographies of scholars in order to discover the importance of scientific achievement. 
It is also evident to us that "al-Kafiya" Ibn Hajeeb had put the rules of the Arabic language that had the greatest influence on the Arabic language and its rules throughout the ages. He had a great influence on the commentators' performance of the Holy Qur'an, as well as in explaining the noble Prophet's hadith, contemplating the geography of languages makes us realize that the Arabic-speaking countries are the ones in the Middle East and North Africa and they with their different dialects, share the common bonds of language, religion, culture and history. As a result, there is a different added material for authors throughout the ages for this language and its literature, so the explanations increased and attention to it became evident, and interest in scholars began to expand in the Islamic world and readers focused on their books, and Ibn Hajeeb was one of those scholars who gained fame in the corridors of the houses of knowledge, and the courses of lessons, and illuminated His works are the shelves of libraries, and his writings on the grammar of the Arabic language have been met by students of the Arabic language from different nations in Africa, Asia and other Islamic countries. His book "Al Kafiya" has achieved unparalleled interest from scholars and learners, and this is what led us to highlight its impact on the development of Arabic in Turkish writings

Ibn Hajeeb is one of the fame of the Arabic language and he is the jurist of the Malikiah. "Al Kafiya" of Ibn Hajeeb is one of the greatest of what he wrote, and it is the greatest of what was written in explaining the Arabic language. Al-Kafiya by Ibn Hajeeb is still being taught in Turkish schools concerned with Arabic language affairs.

The name of Ibn Hajeeb appeared in the internals of the books of translations and compilations, and its pages included praise of a number of other scholars, writers and men of knowledge. He came to me repeatedly due to opinions and testimonies, and I asked him about problematic issues in Arabic, and he answered the most eloquent answer, with much silence and complete firmness.

Al-Dhahabi says: And he was one of the smartest scholars, a head in Arabic and a science of sight, he taught at the Mosque of Damascus, and with the Maliki nouria, and his companions graduated with him and his works were followed by the stirrups. Ibn Hajeeb disagreed with the grammarians on many topics of their books regarding grammar.

Indeed, we say that Ibn Hajeeb is one of the most talented scholars who have served the Arab and Islamic heritage, and have compiled books that made those coming to his acquaintances seek to learn from him, and it seems that his value and fame are due to the fact that he was a good abbreviation of the books of the advanced ones of his time, skilled at graduating rules and examples, in addition to that. The travelers praised him in their travels, and restricted what was said about him in their notebooks, such as al-Abdari and Tajibi. 


\section{مقدمة}

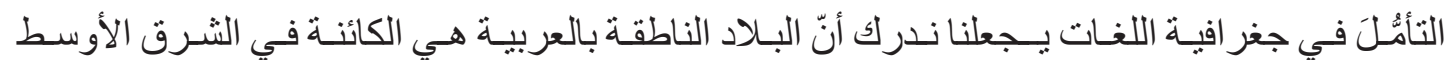

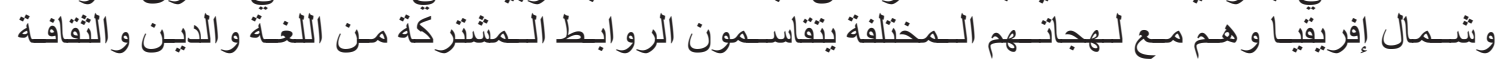

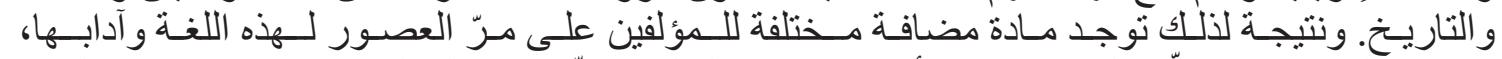

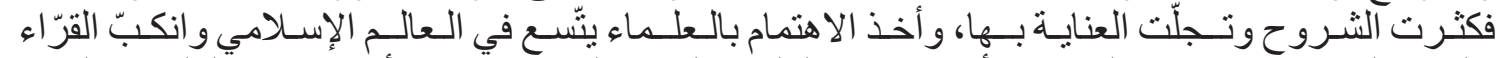

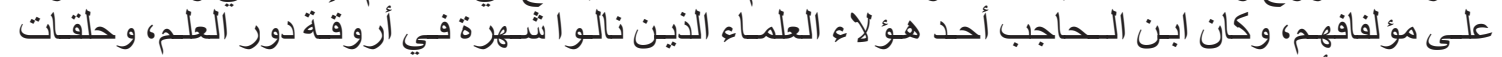

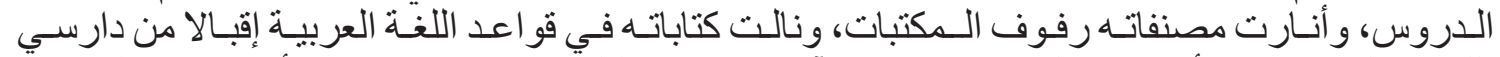

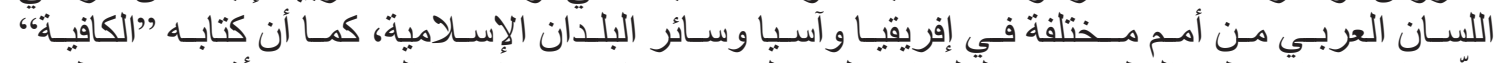

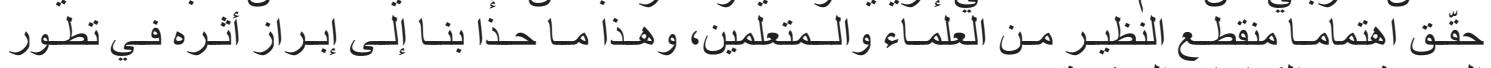

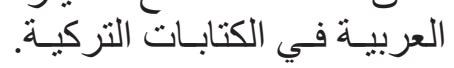

ابن الحاجب: حياته و آثاره

عصره وبيئته التقافية

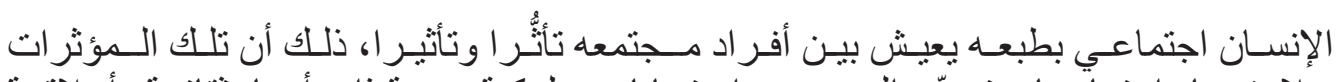

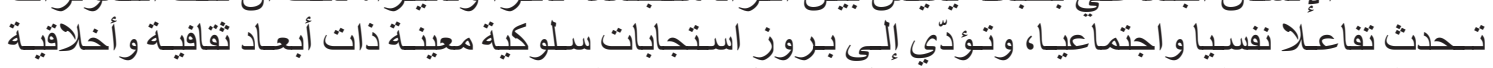

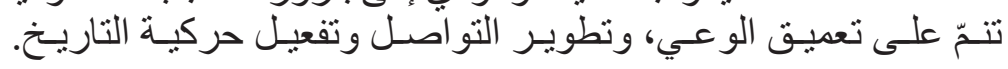

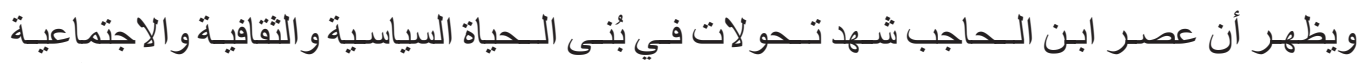

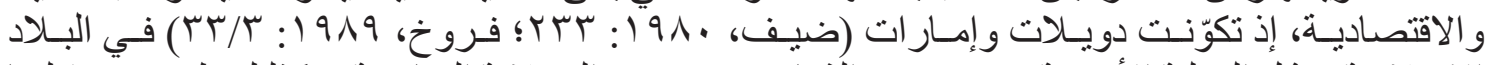

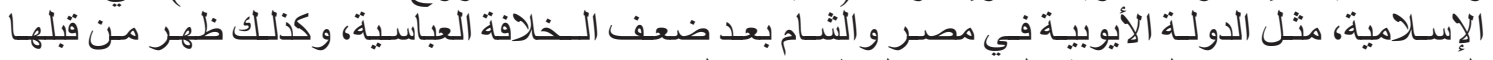

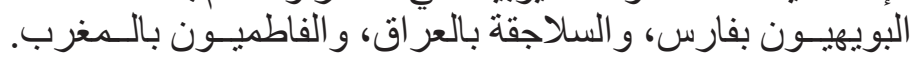

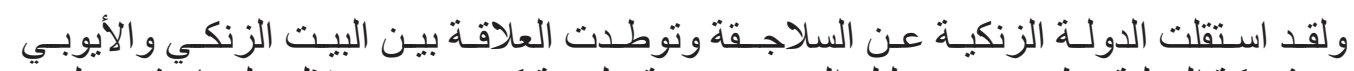

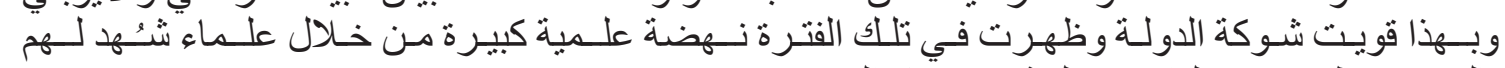

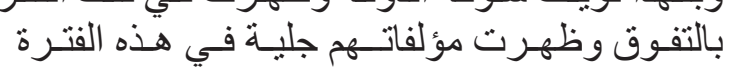

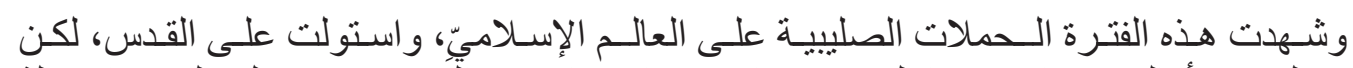

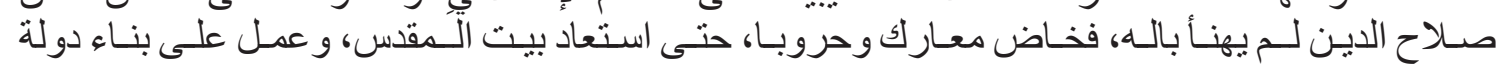

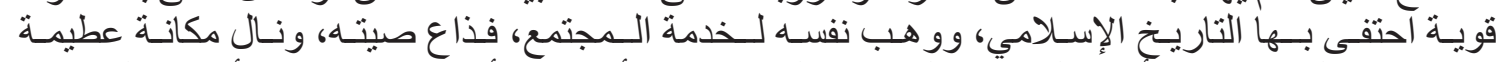

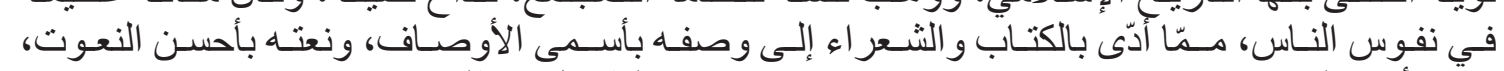

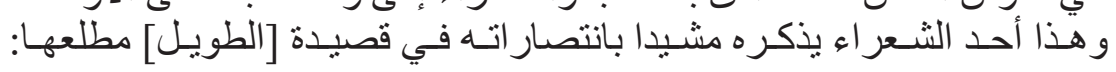

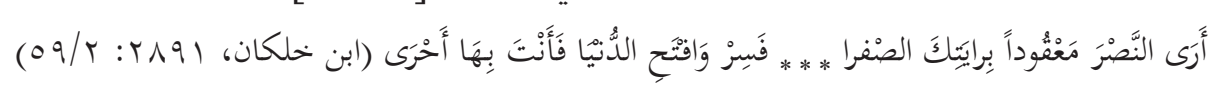

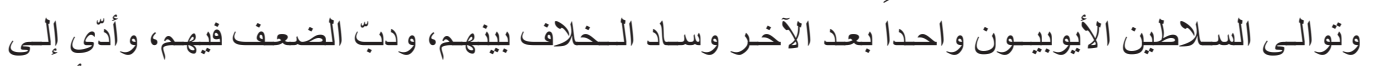

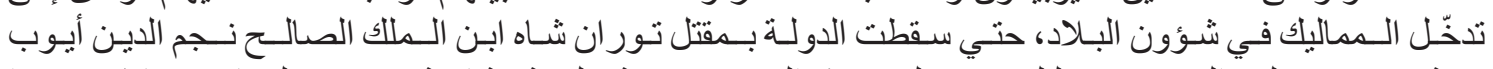

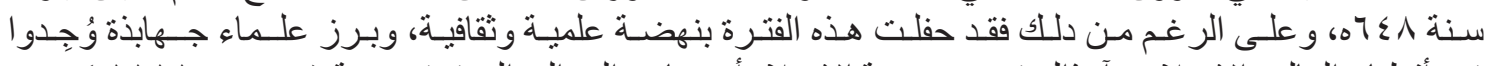

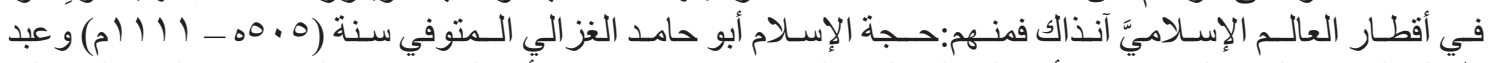

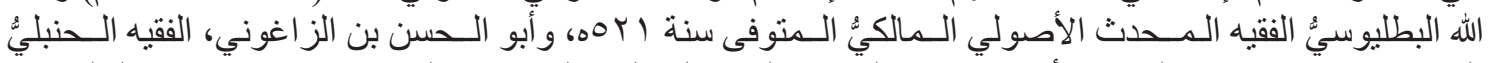

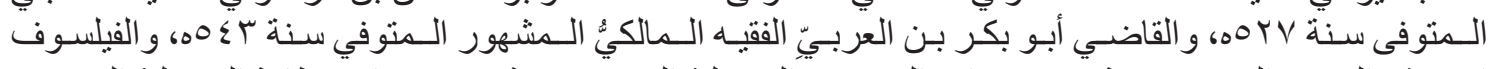

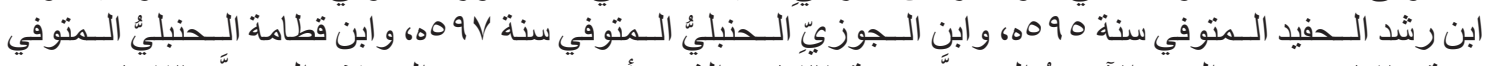

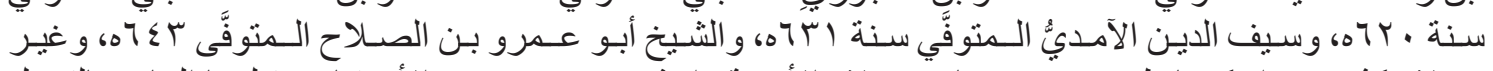

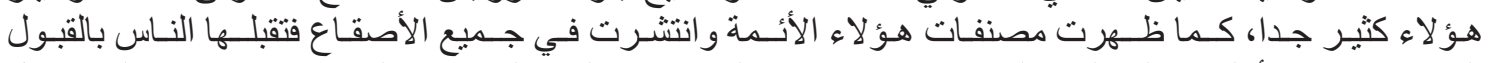

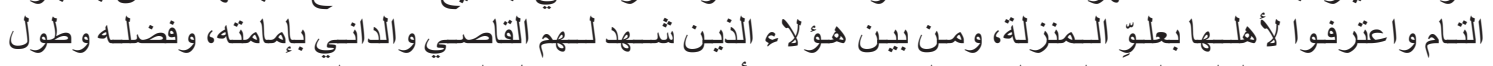

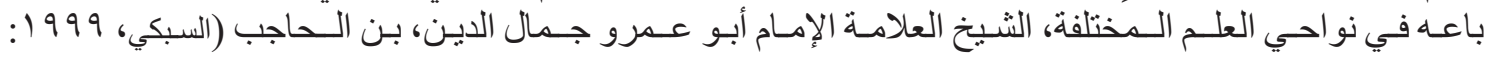




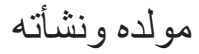

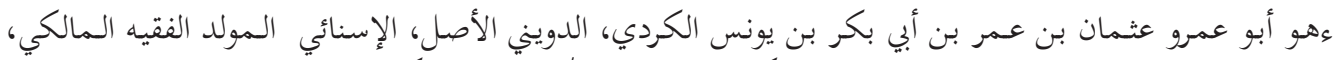

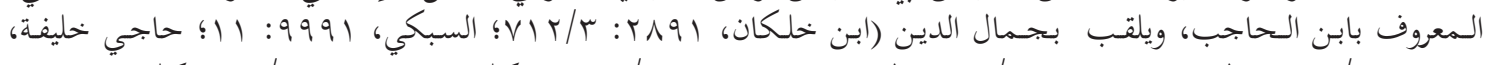
צا

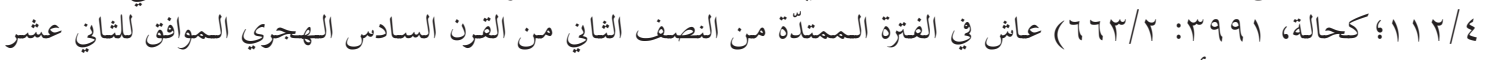

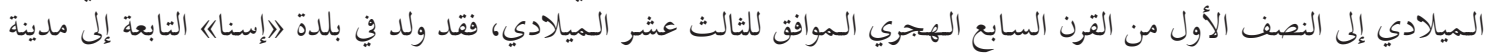

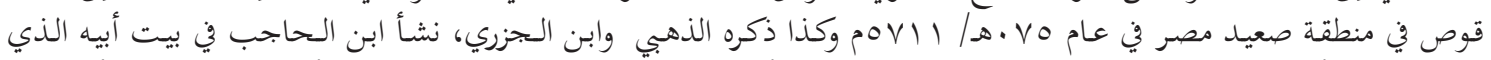

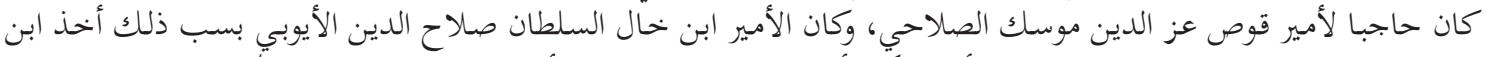

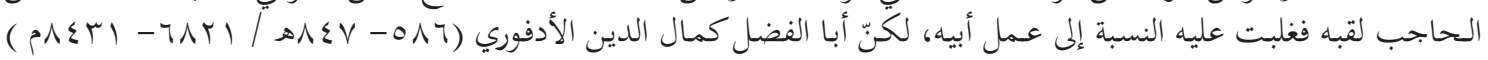

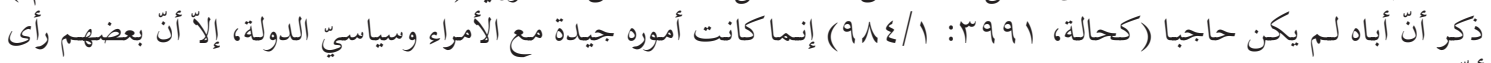

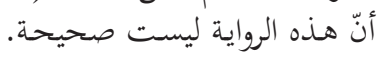

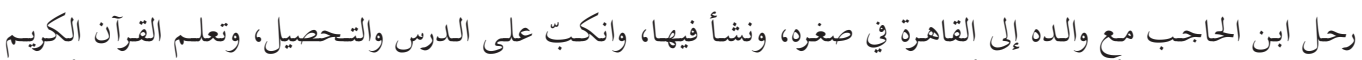

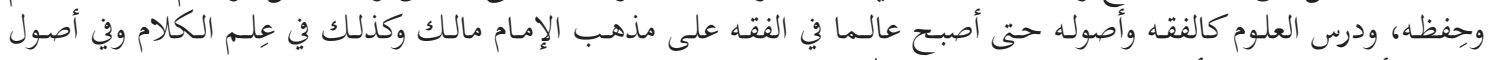

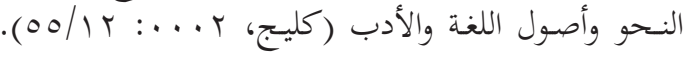

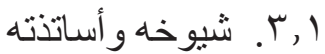

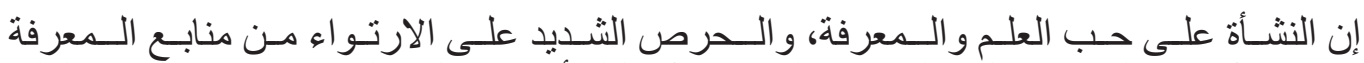

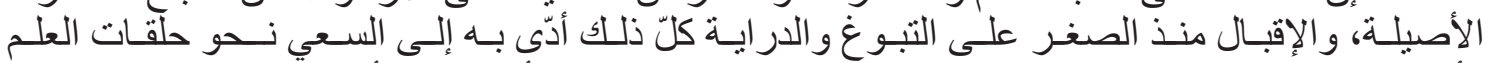

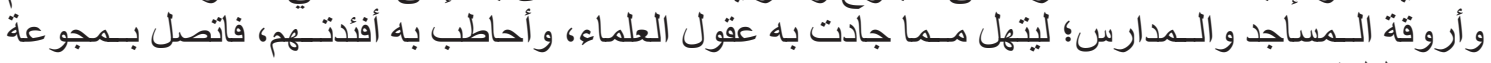

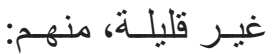

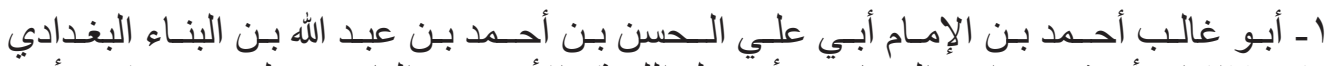

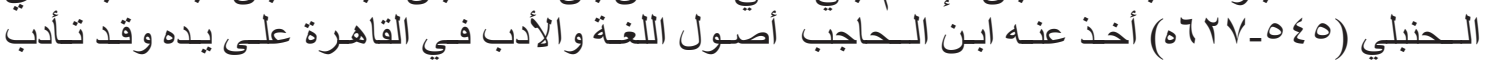

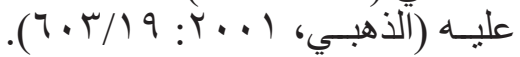

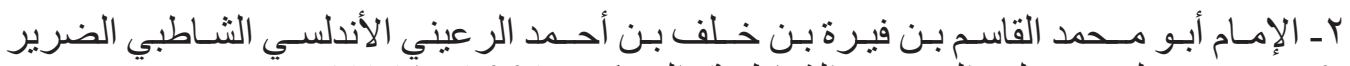

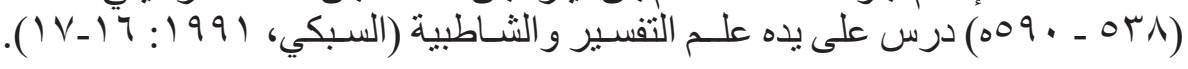

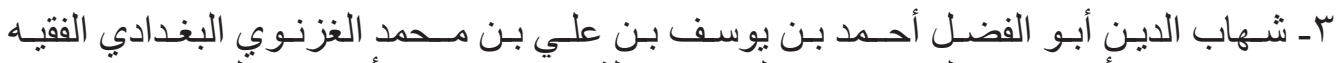

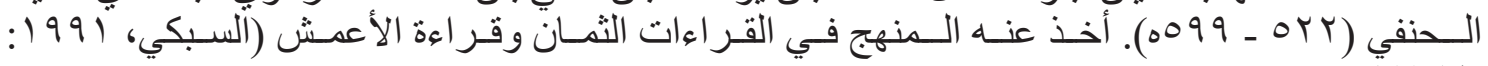

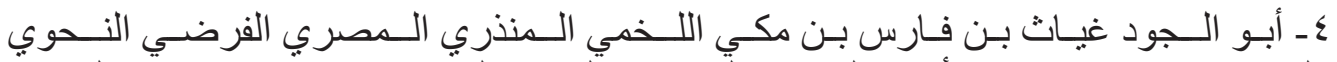

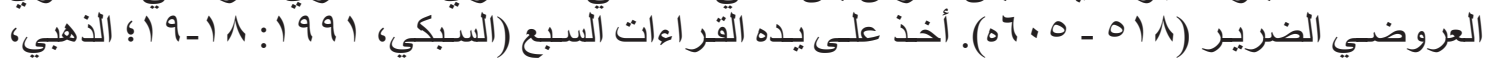
. $(\varepsilon \vee \leqslant / r i$ : $Y$...

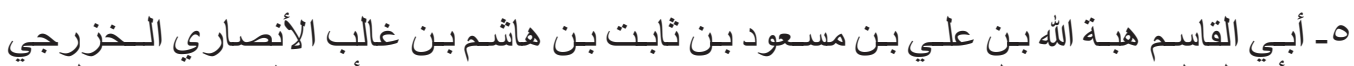

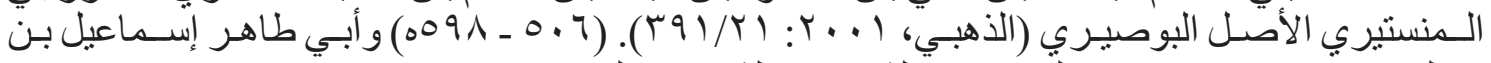

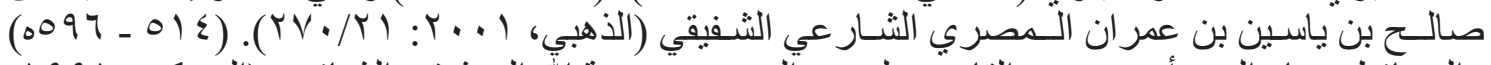

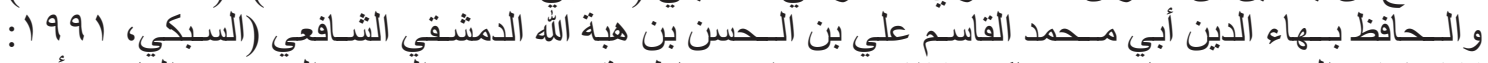

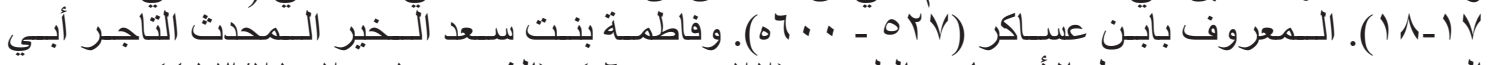

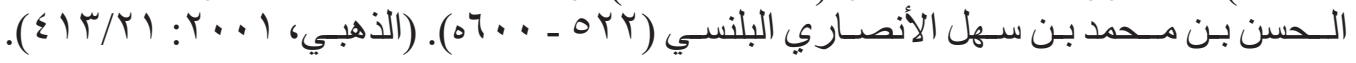

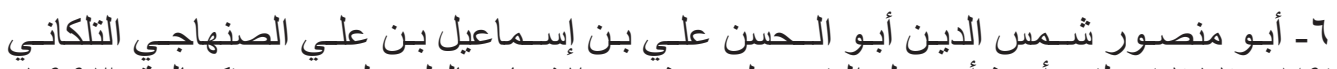

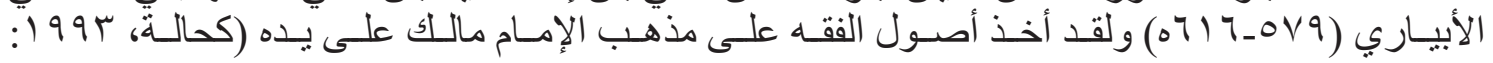




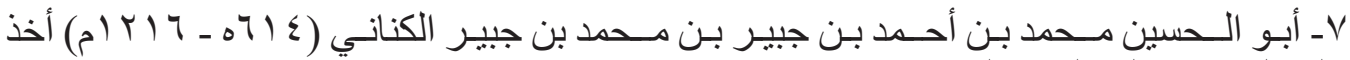

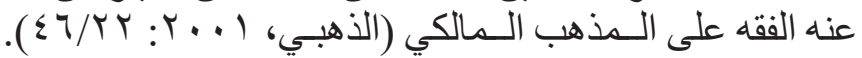

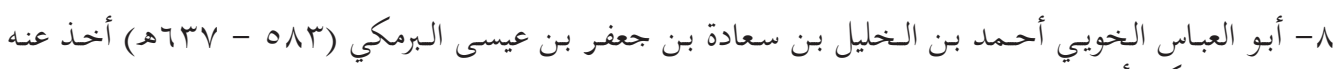

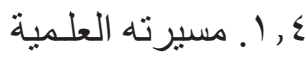

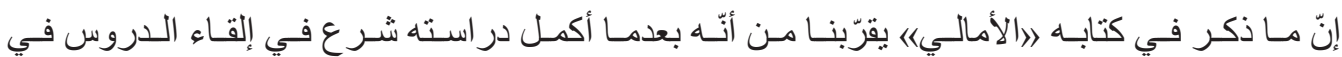

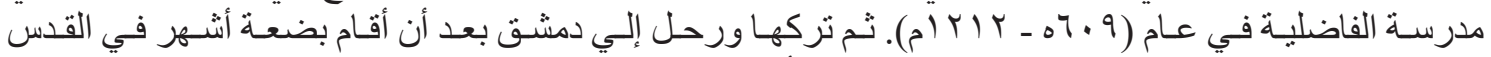

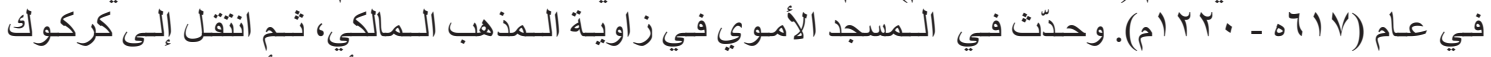

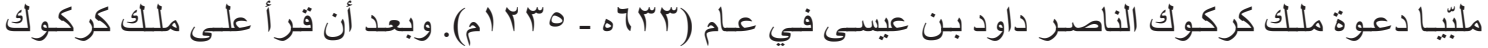

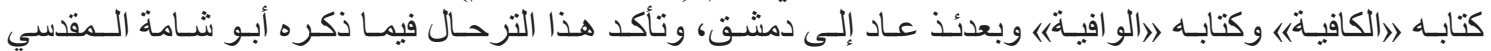

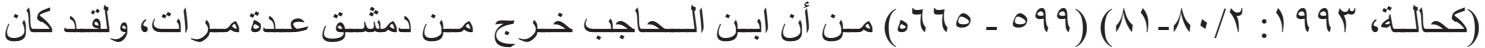

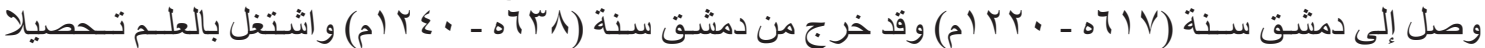

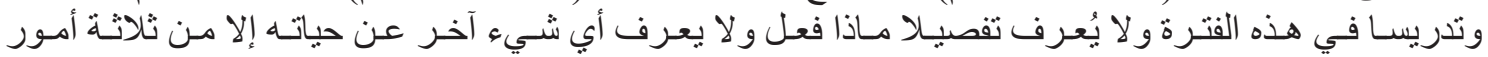

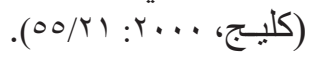

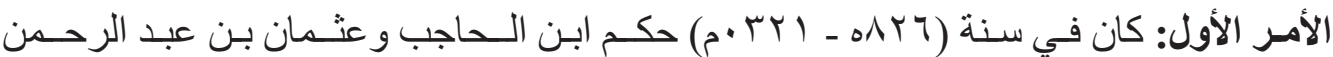

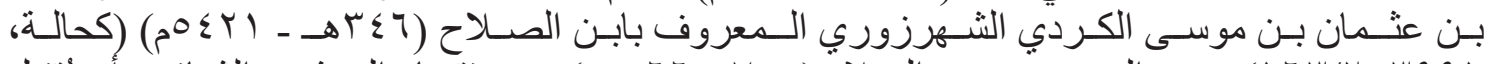

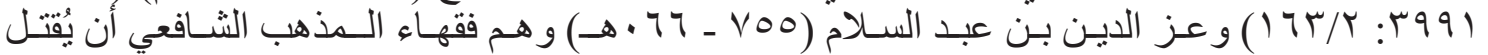

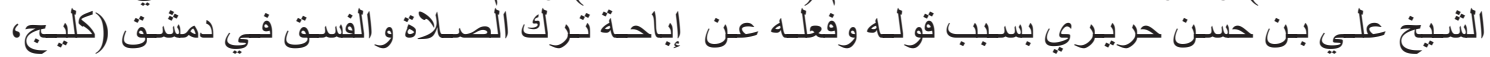
. $00 / 1 \mathrm{l}: \cdots \cdot \mathrm{r}$

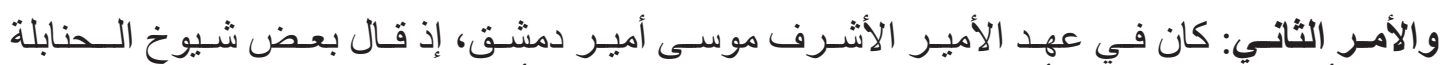

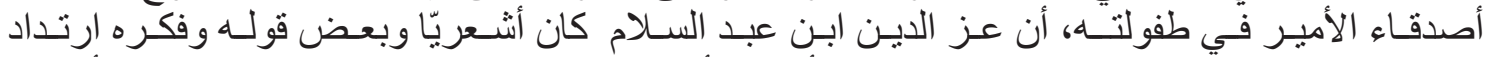

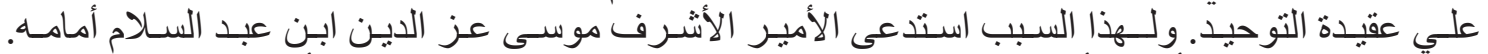

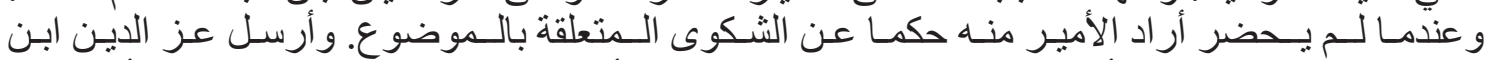

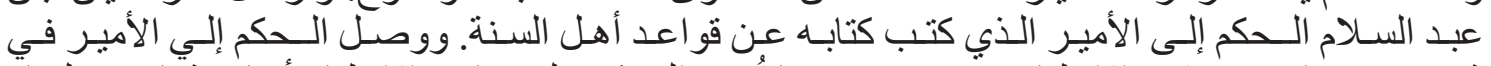

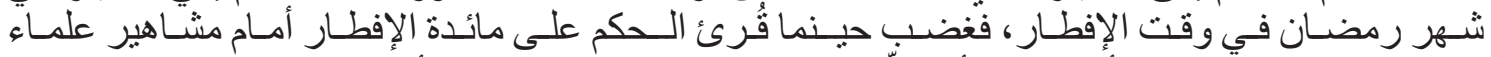

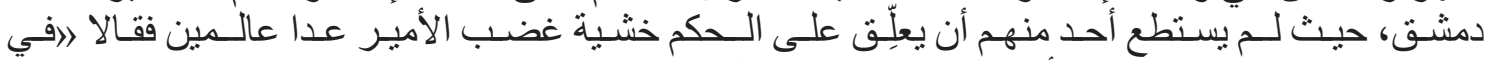

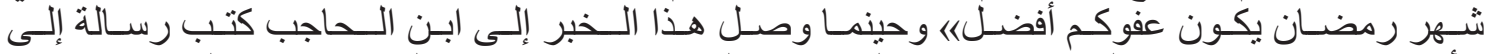

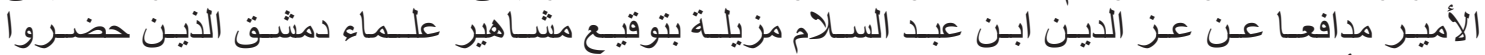

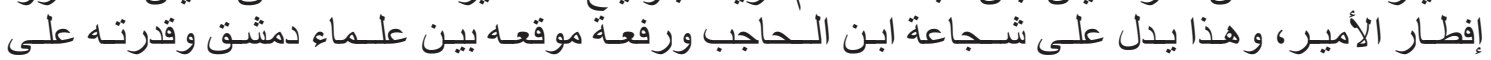

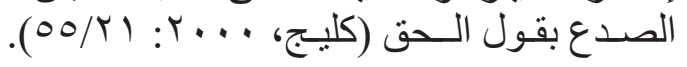

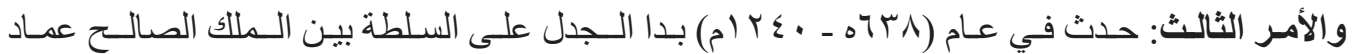

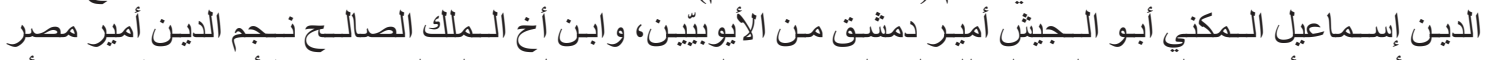

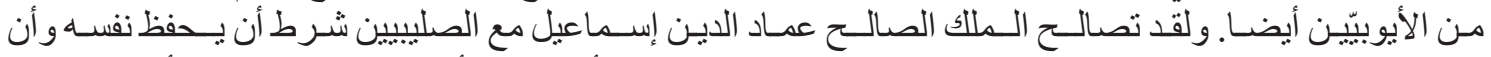

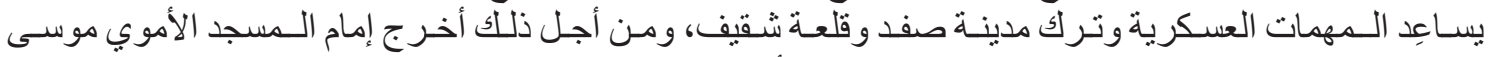

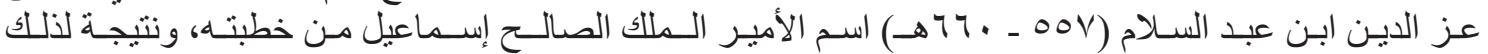

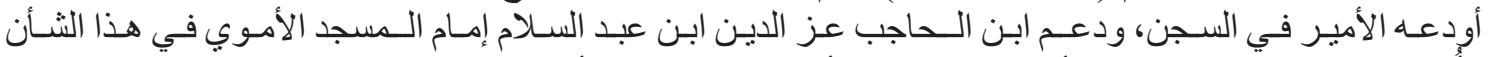

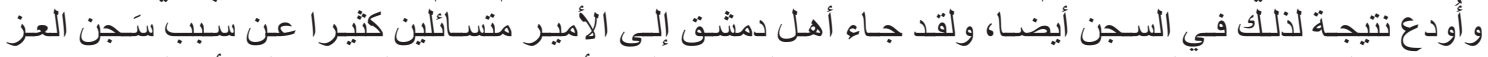

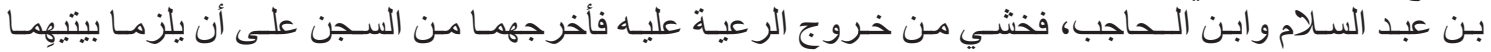

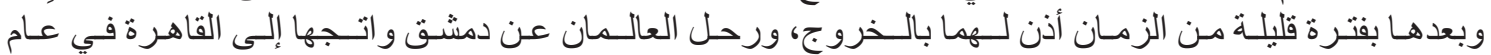




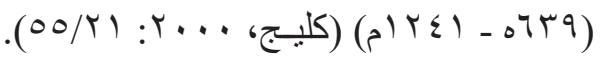

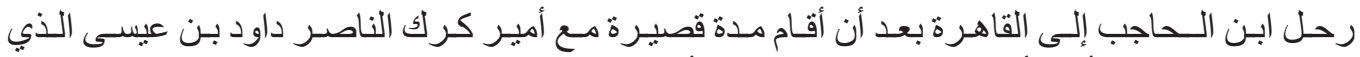

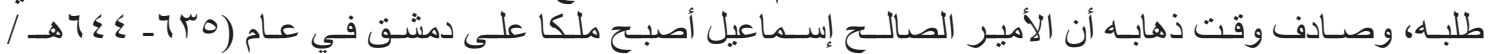

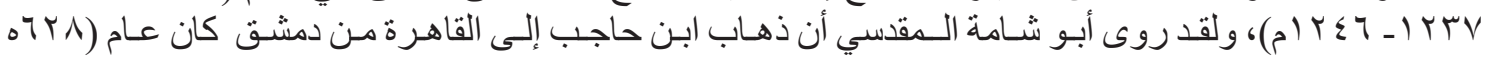

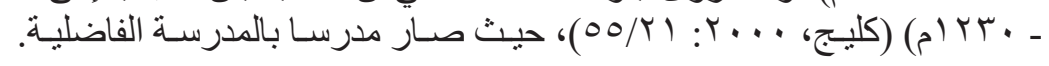

0 1, 1. تلاميذه

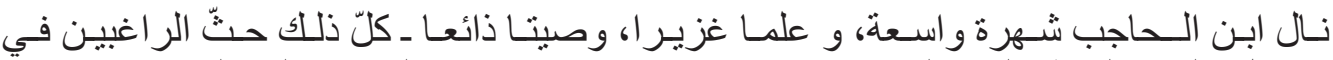

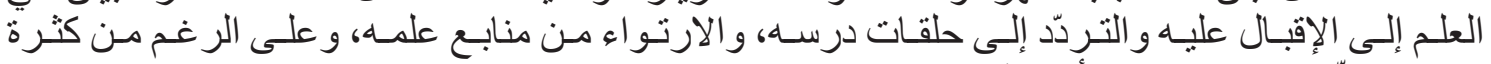

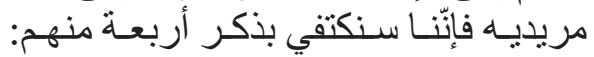

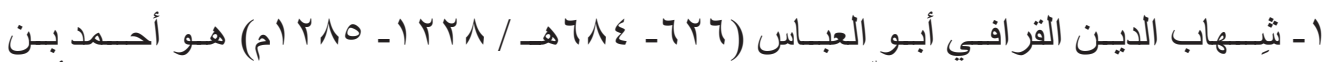

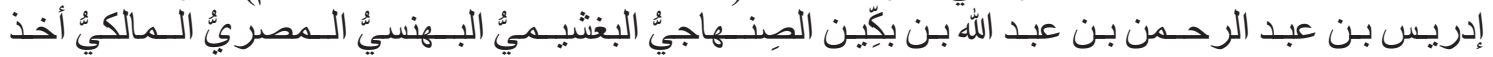

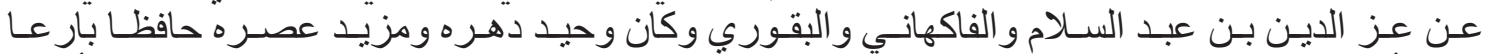

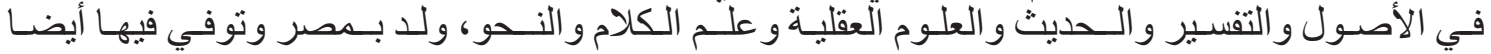

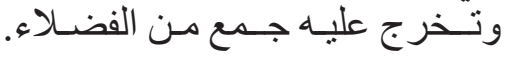

\section{من تصانيفه:}

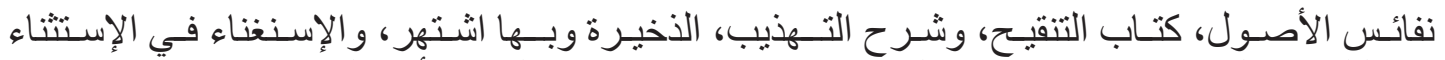

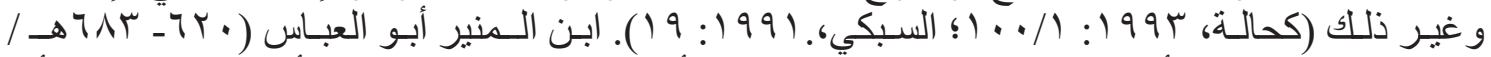

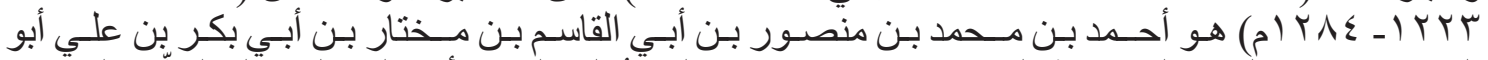

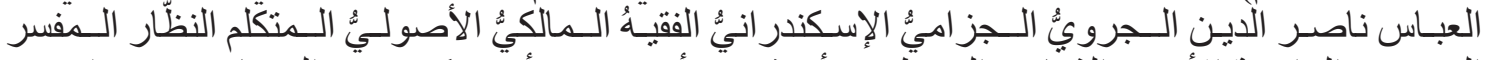

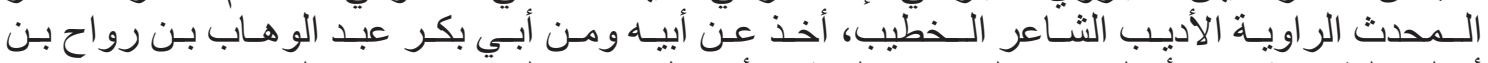

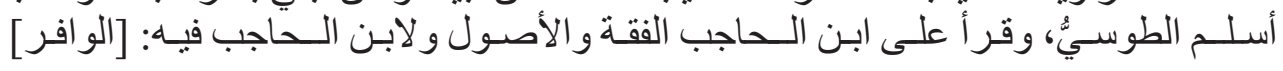

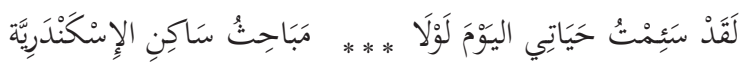

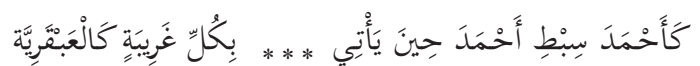

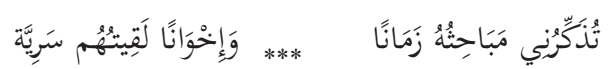

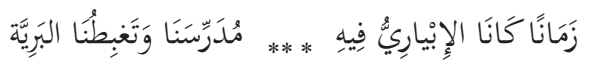

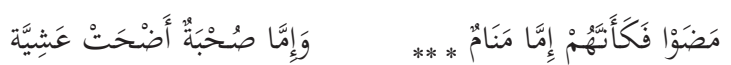

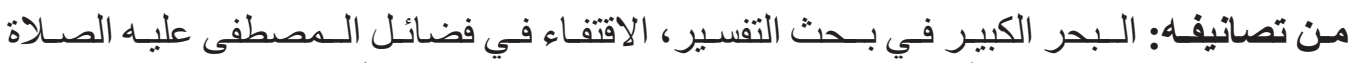

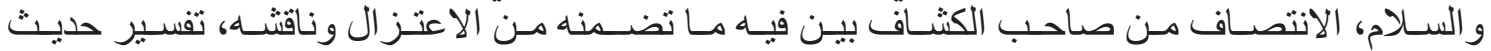

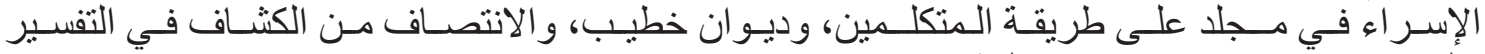

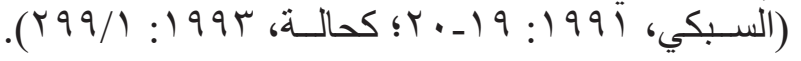

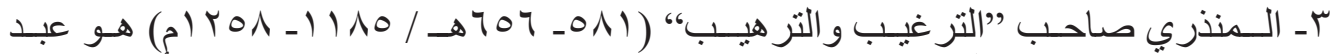

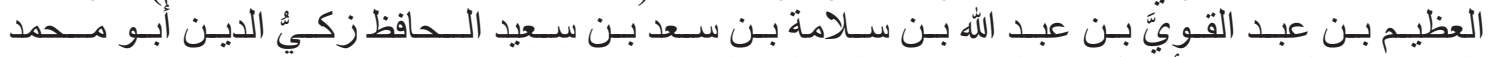

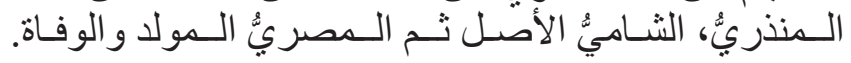

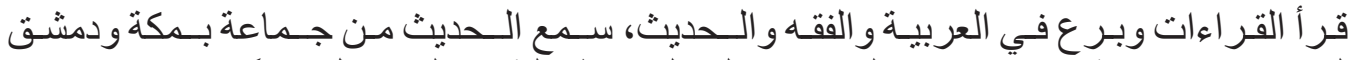

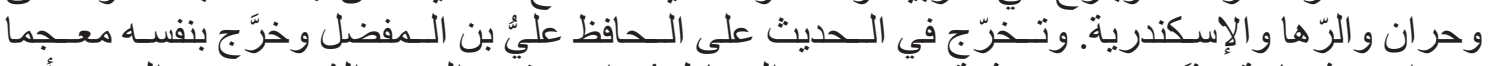

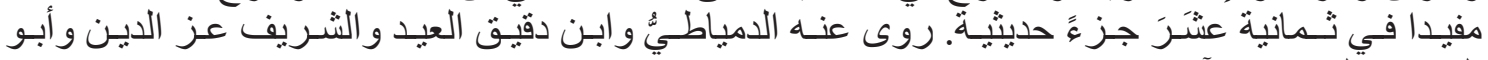
الـحسن اليونينـيُّ وآخرين.

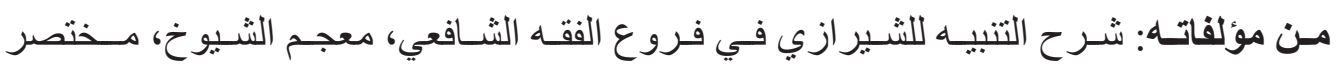




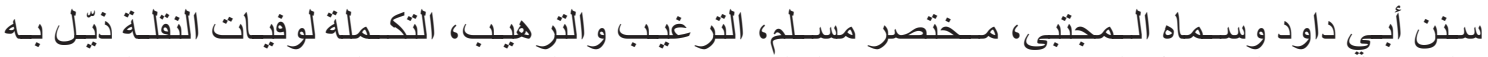

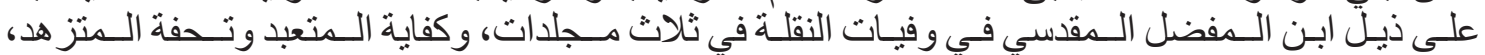

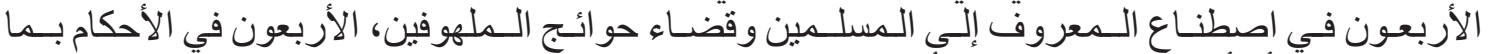

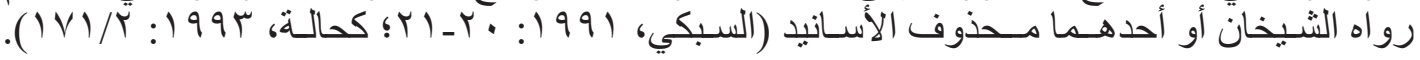

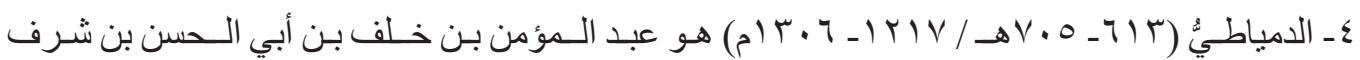

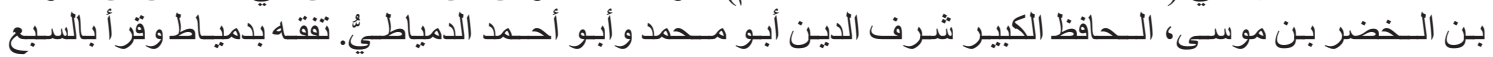

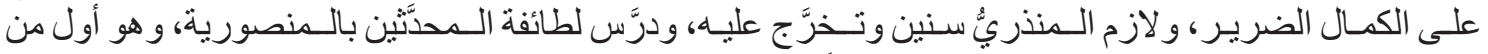

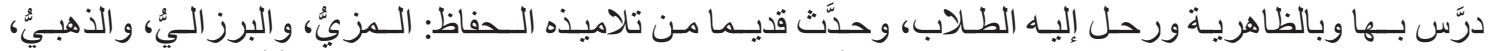

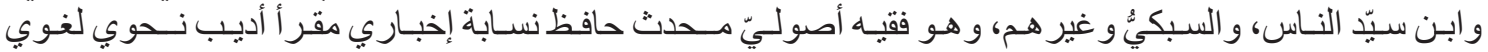

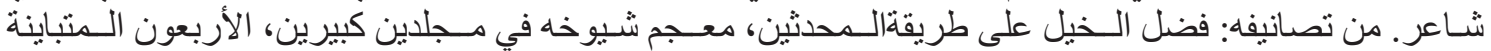

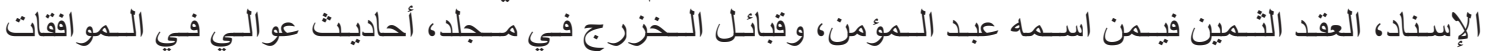

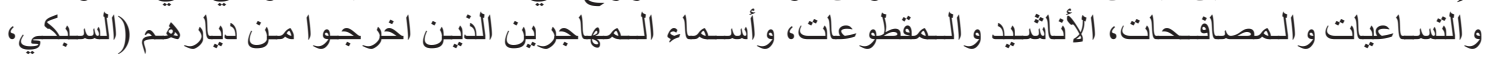

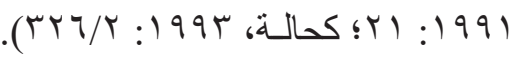

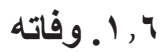

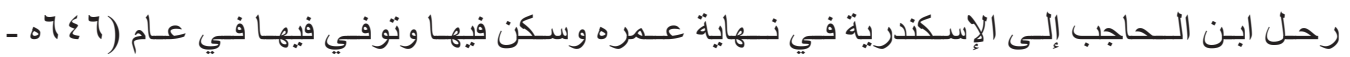

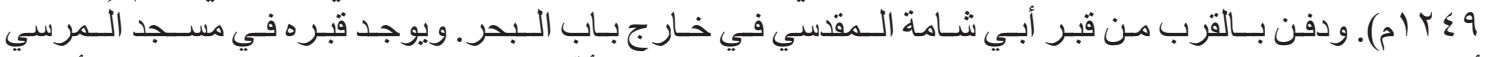

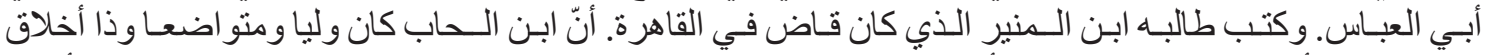

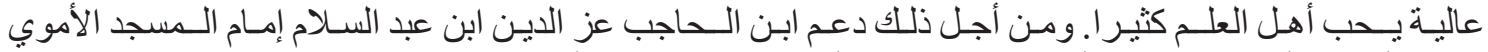

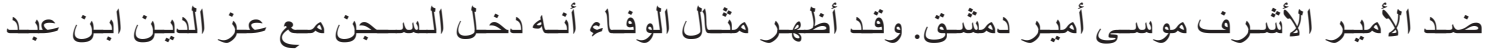

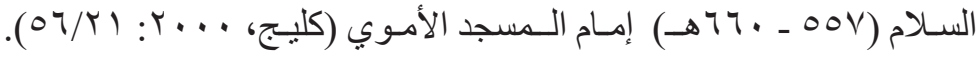

ثناء العلماء عليه

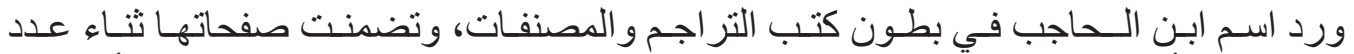

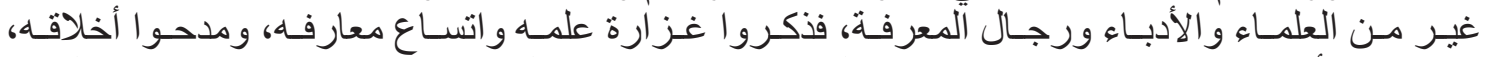

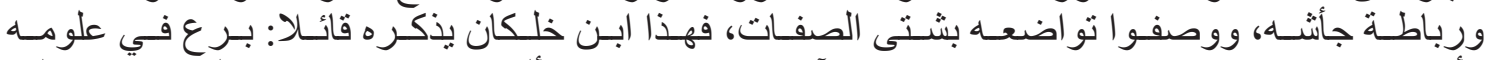

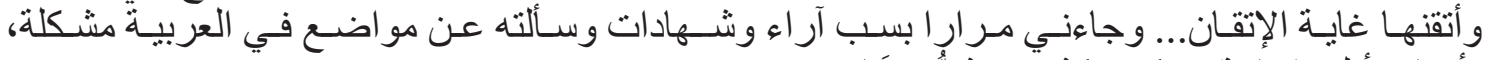

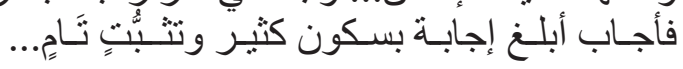

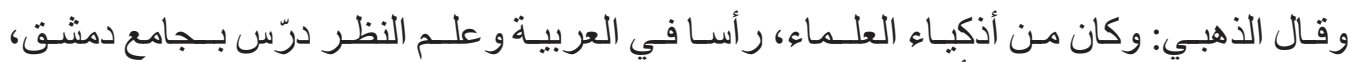

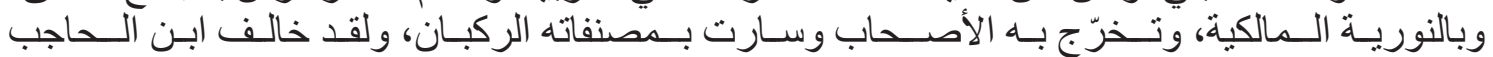

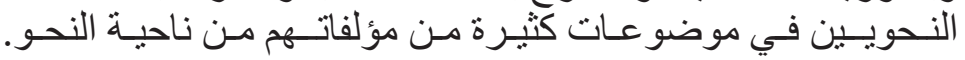

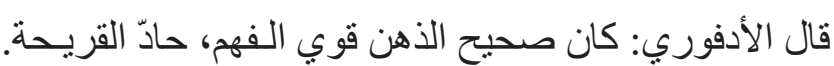

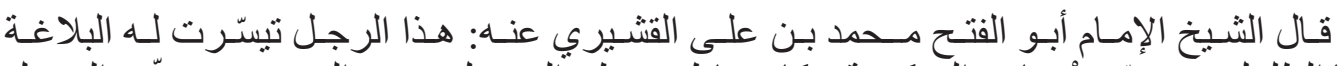

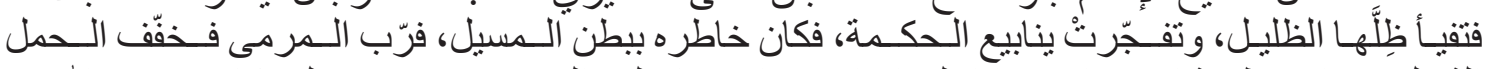

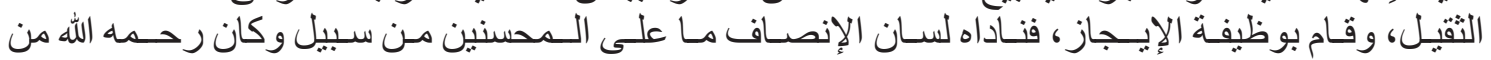
المحسنين الصالحين الـتقين.

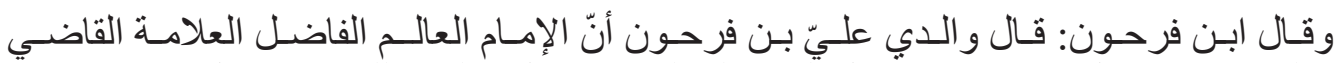

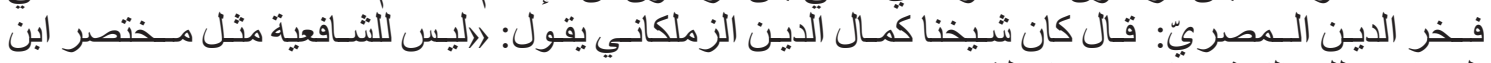

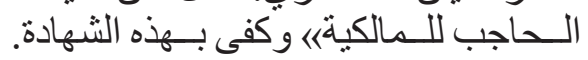

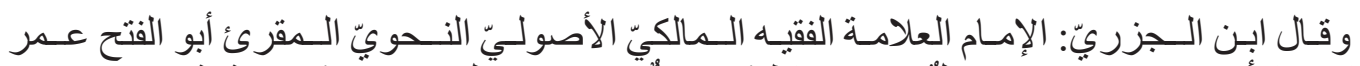

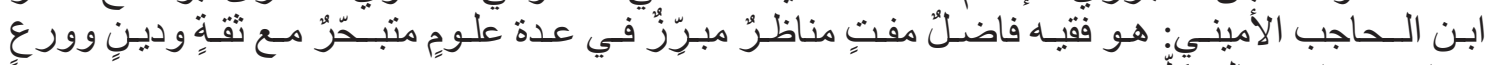

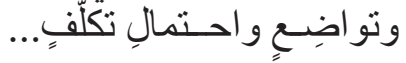




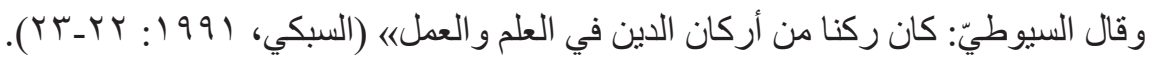

1, 1 ا ـ آثاره وتتآليفه

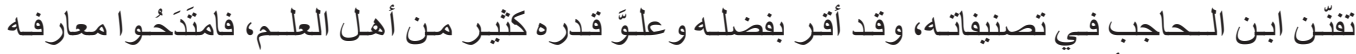

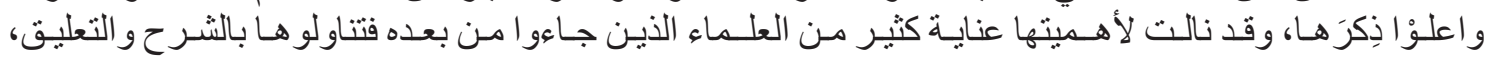

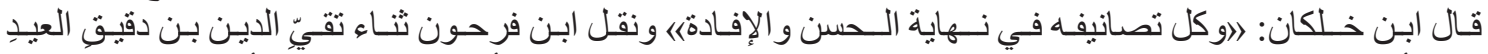

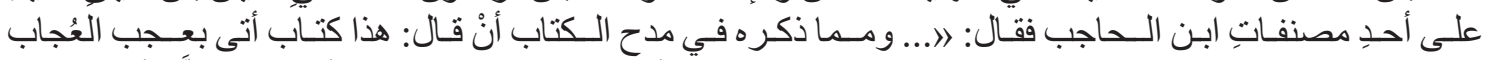

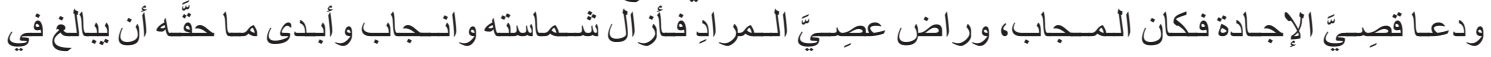

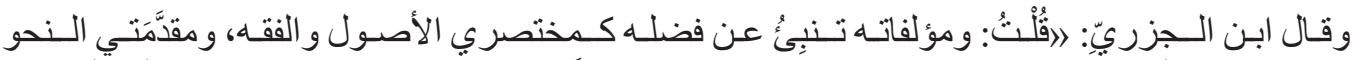

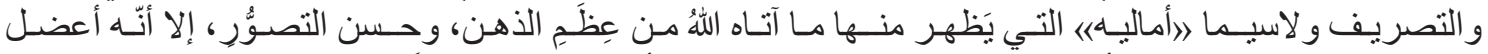

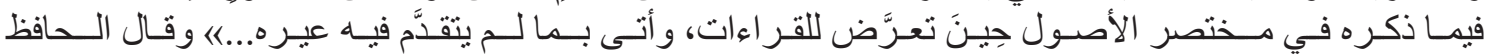

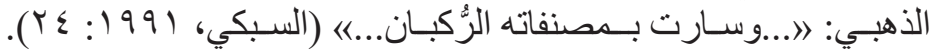

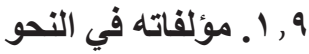

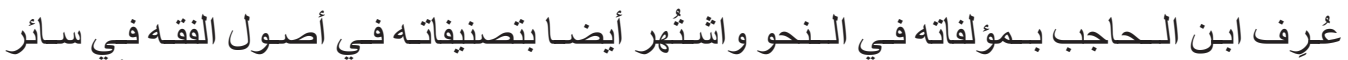

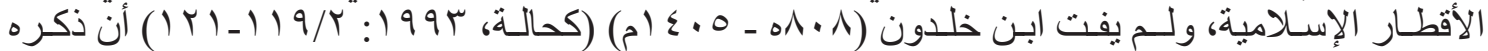

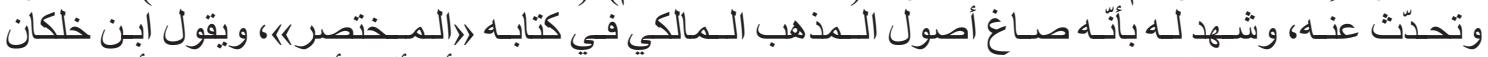

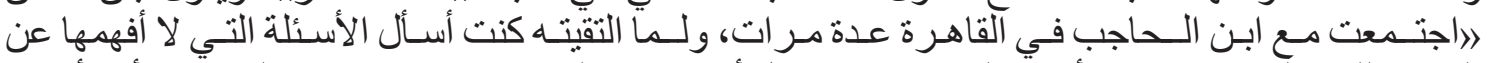

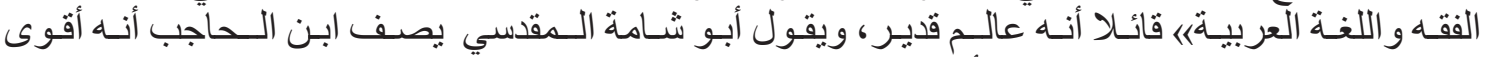

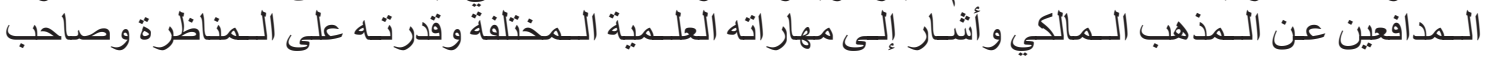

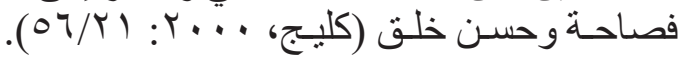

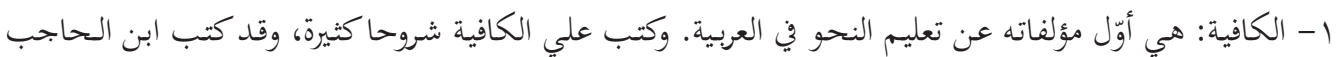

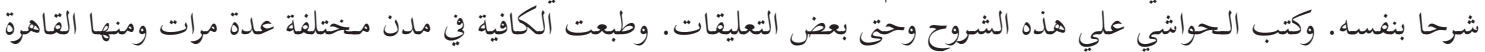

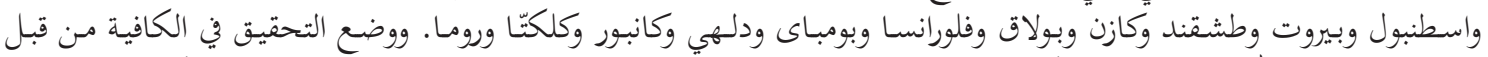

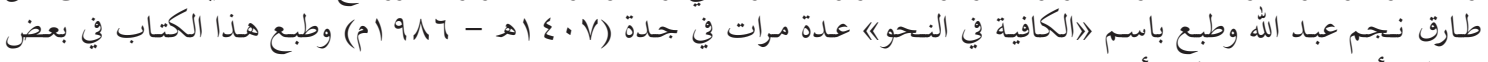
الدول الأوروبية وإيران وتركيا أيضا.

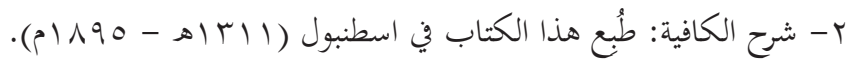

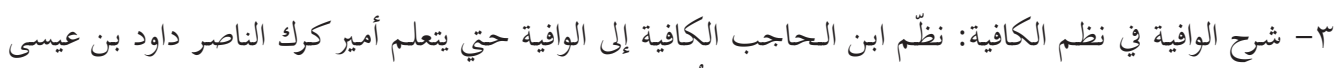

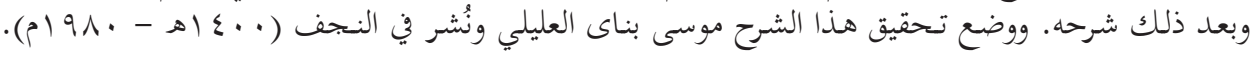

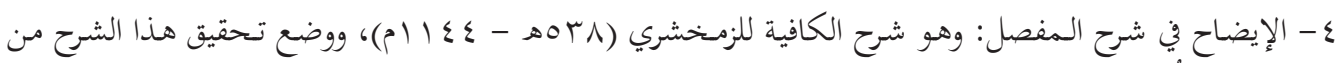

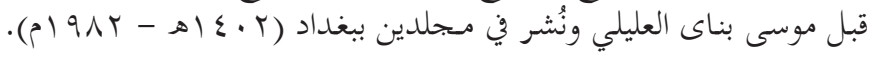

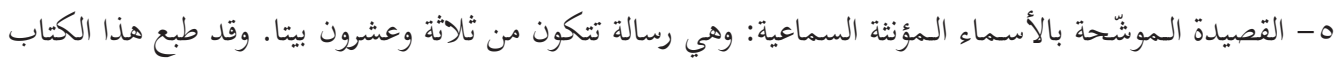

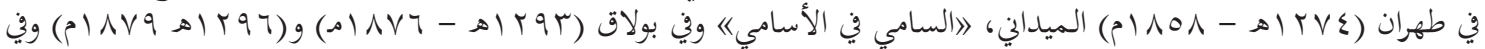

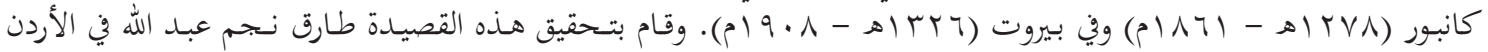

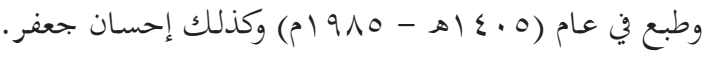

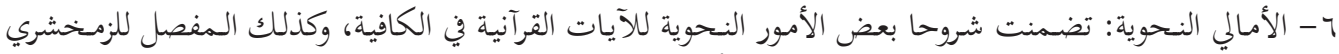

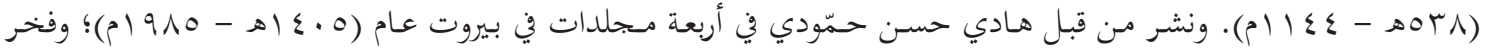

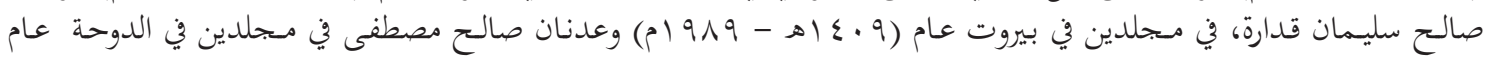

$$
\text { ( () }(\leqslant \Lambda \uparrow-ه) \varepsilon \cdot 7)
$$

V- رسالة في العشرة: أوردها عن الاستعمال أن كلمة العشرة في أوائلها وأواخرها ونشرها هادي حسن حمودي عن 


$$
\begin{aligned}
& \text { هاتين الرسالتين في علاوة أماليه بيروت عام (0 . ع اهـ - } 910 \text { (م). } \\
& \text { 1 - شرح ابن الحاجب على كتاب المقتفي للمبتدي لسيبويه. } \\
& \text { 9- المكتفي للمبتدي شرح على كتاب شرح الإيظاح لأبي علي الفارسي. } \\
& \text {. إعراب بعض آيات القرآن العظيم. }
\end{aligned}
$$

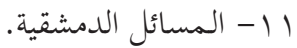

$$
\begin{aligned}
& \text { r إ- شرح المقدمة الجزولية. } \\
& \text { كل ما مر من مؤلفاته في النحو ا إلى با (السبكي، (99 19: } 199 \text { (ب). } \\
& \text {. } 1 \text {, } 1 \text { ـ مؤلقاته في الصرف مون }
\end{aligned}
$$

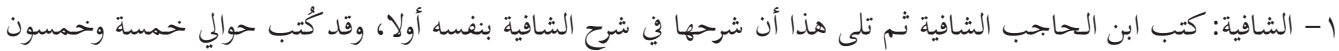

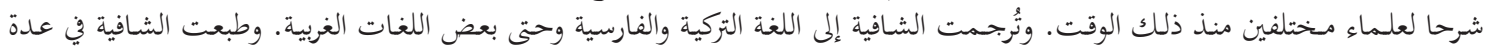

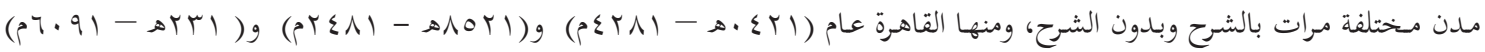

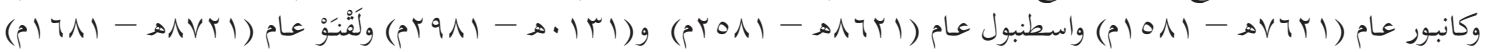

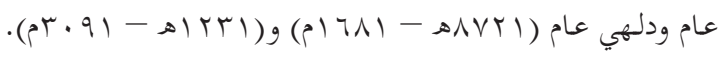
ץ- شرح الشافية: يوجد من هذا الكتاب نسخ كثيرة وقام بالتحقيق حسن أحمد العثمان ولكن لم يطبع حتى الآن (السبكي،

$$
\text { 1, 11 ا مؤلفاته في الأدب والعروض }
$$

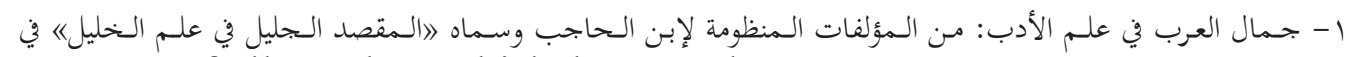

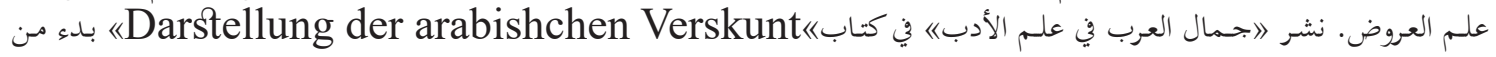

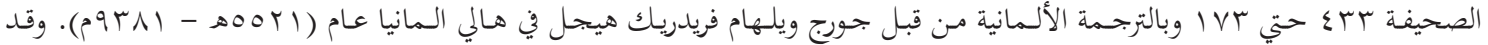

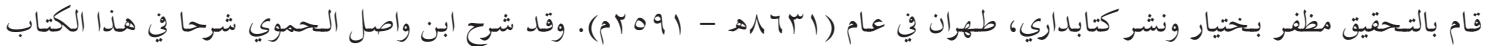

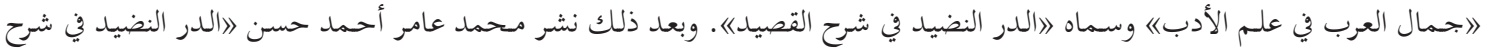

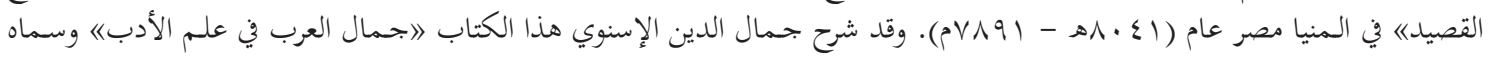

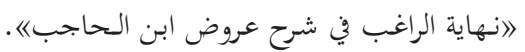

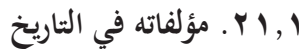

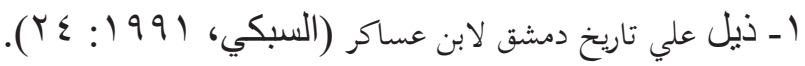

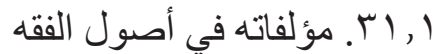

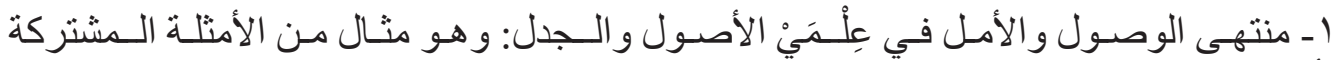

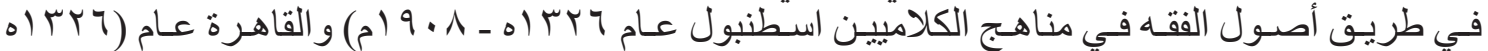

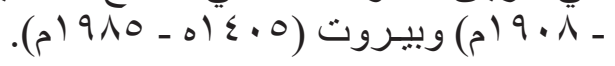
r ـ شرح منتهى الوصول و الأمل في علمي الأصول و الـجل في ثلاثة مؤلفات:

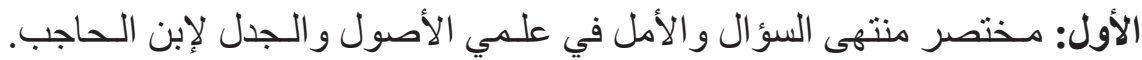

$$
\text { الثالثي: المختصر الكبير لإبن الحاجب. }
$$

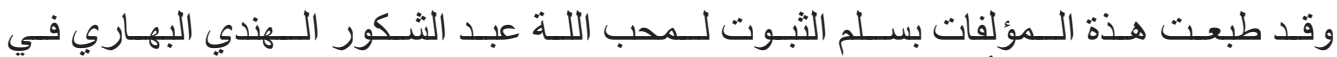

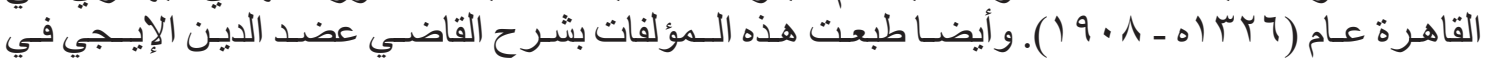




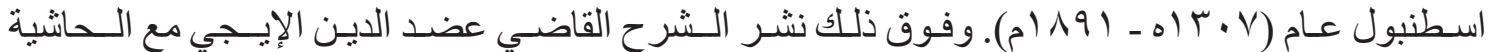

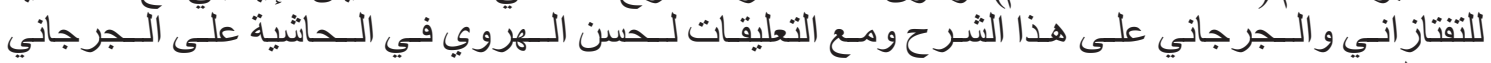

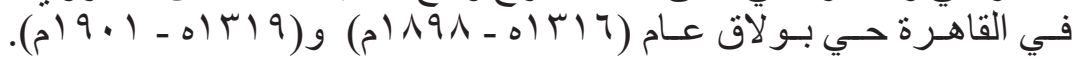

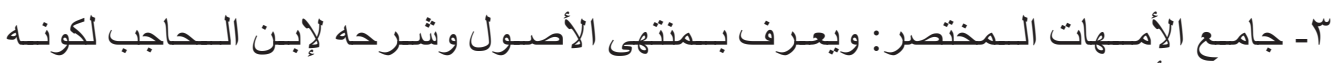

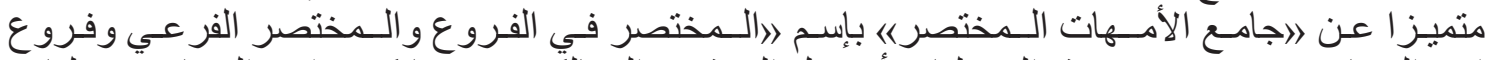

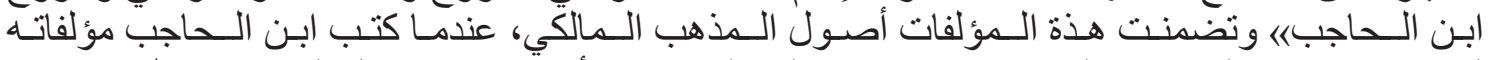

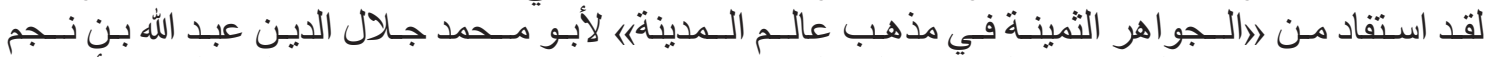

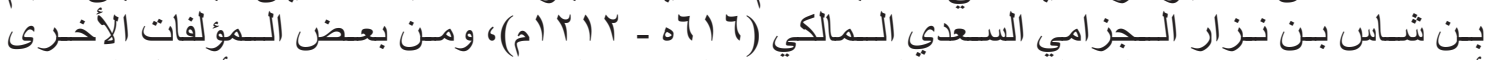

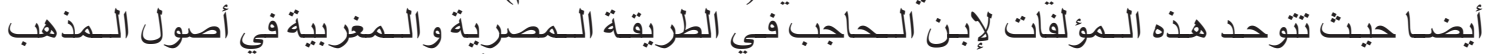

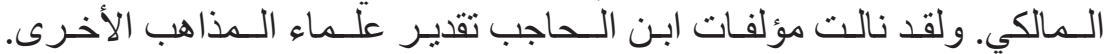

$$
\text { ب. شروح الكافية }
$$

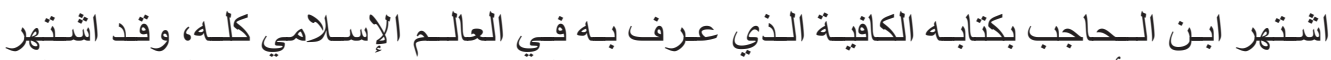

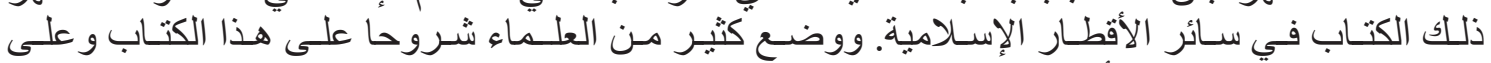

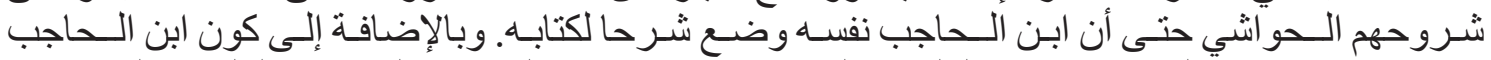

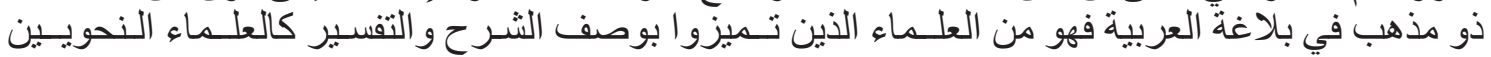

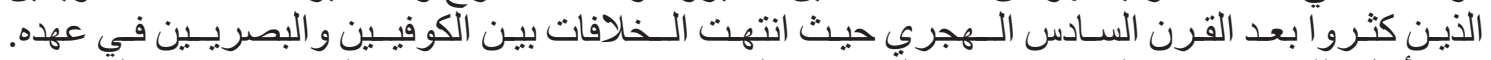

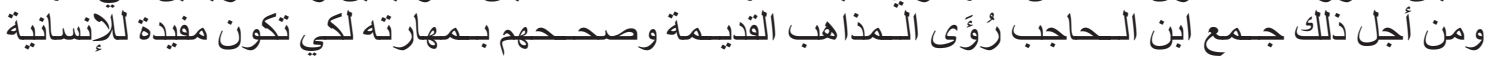

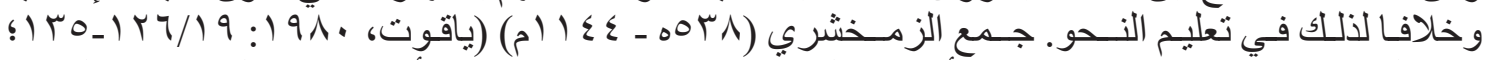

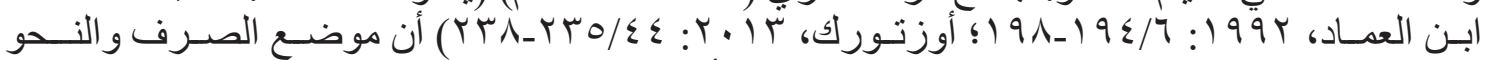

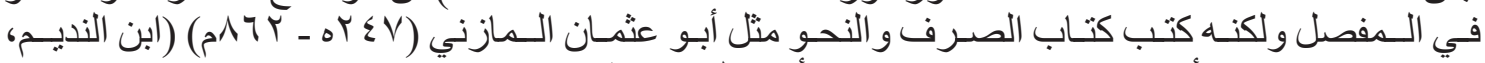

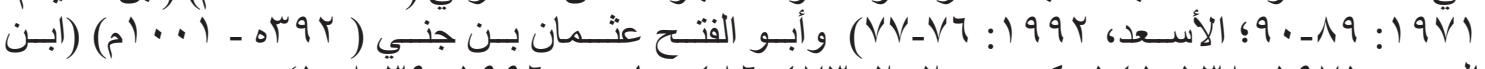

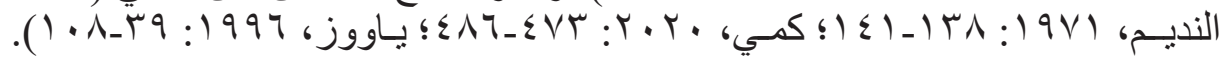

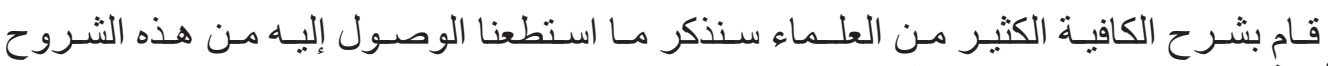

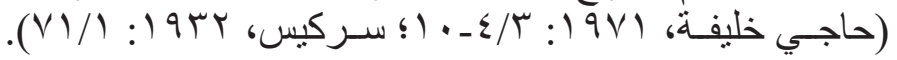

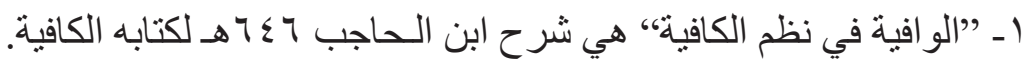

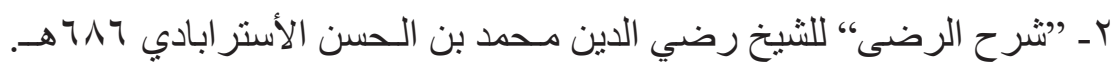

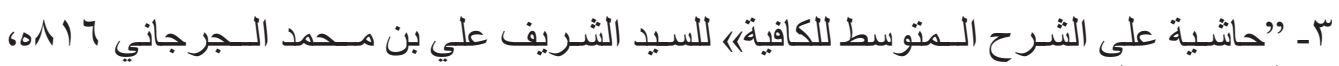

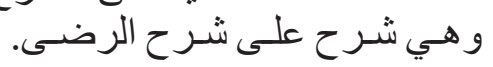

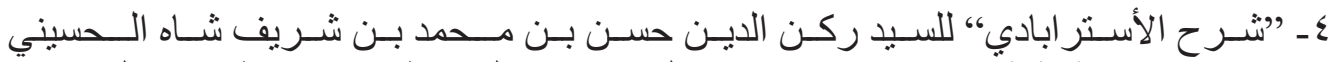

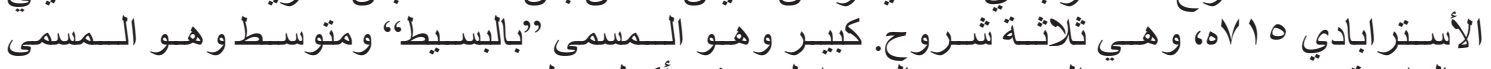

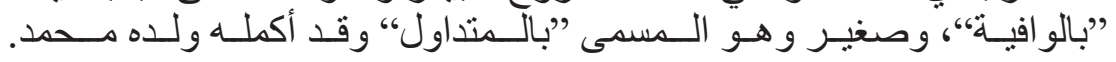

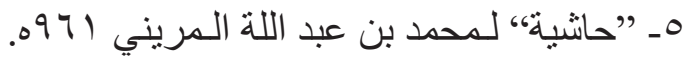

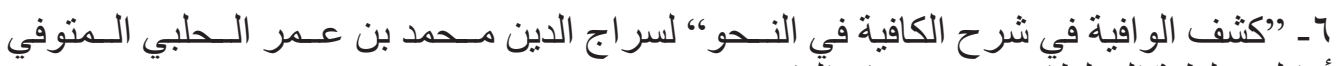

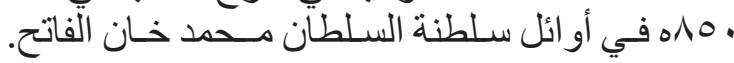

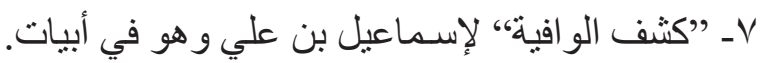

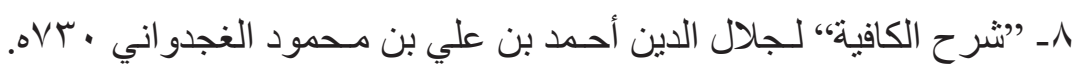

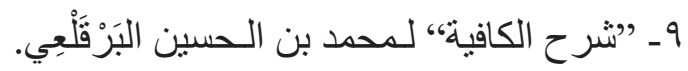

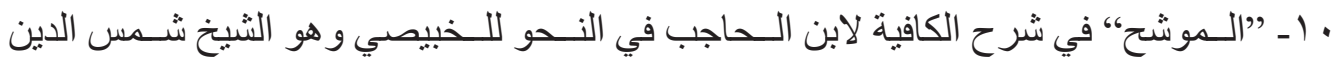


مـحمد بن أبي بكر بن مـحمد الـخبيصي اسلوه و عليه حاثـية للسبيد الثـريف.

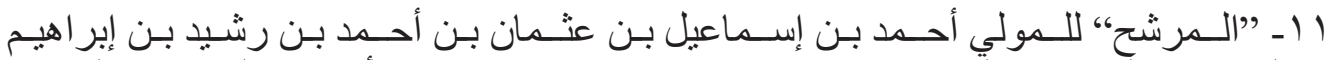

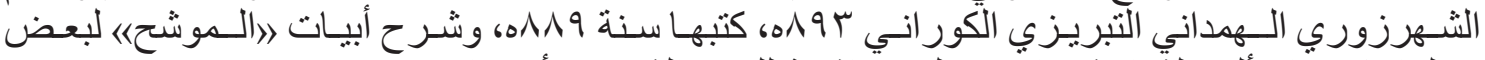

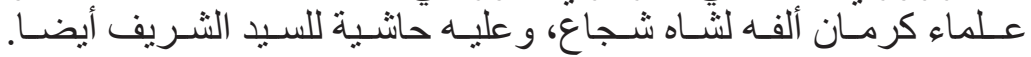

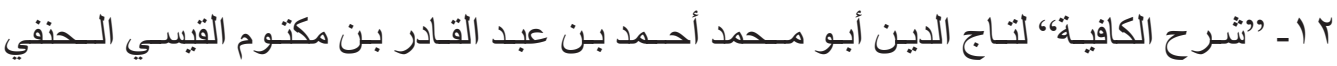

ك ا ـ "الثر ح السعيدي، لنجم الدين سعيد العجمي.

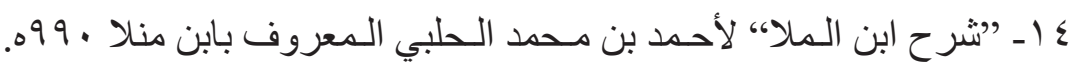

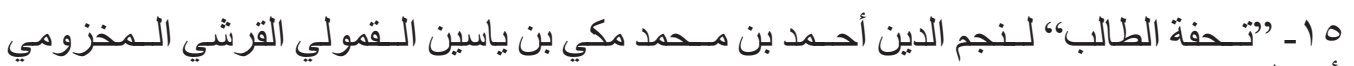

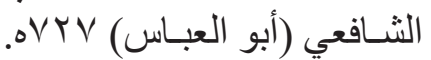

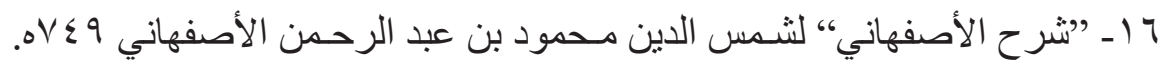

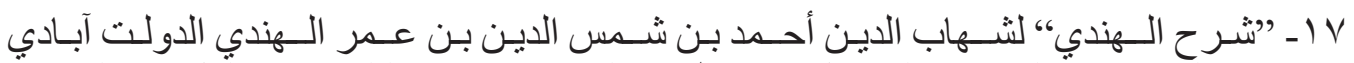

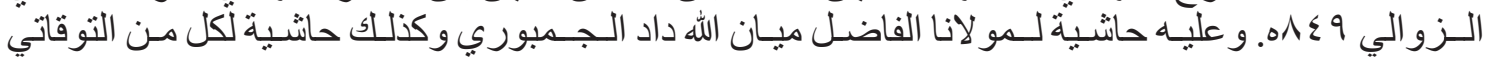
و الكزرونسي ولغيـاث الديـن منصـور.

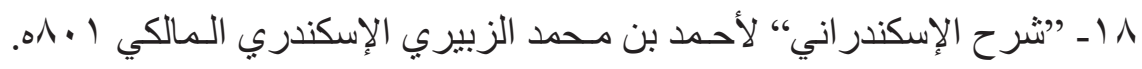

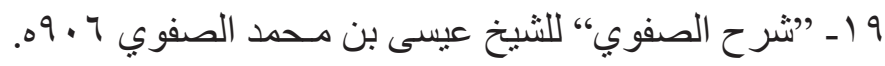
• r ـ "شر ح الفناري“، لعلاء الدين علي الغفاري الفناري.

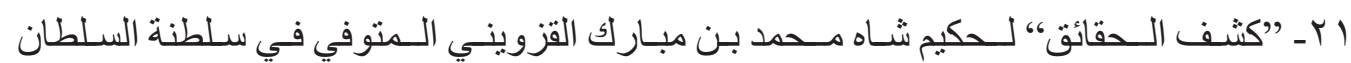
سـليمان خـان.

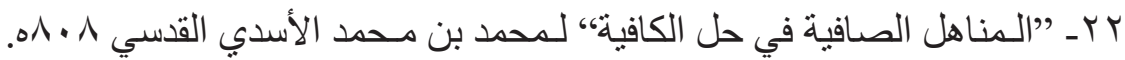

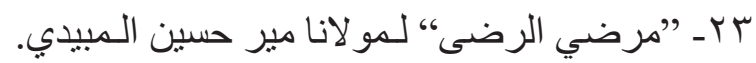

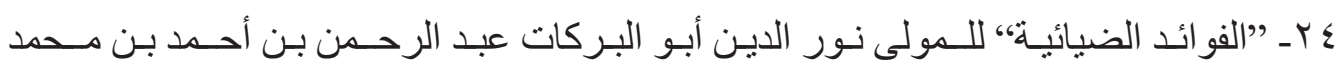

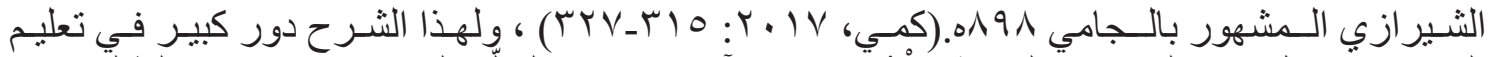

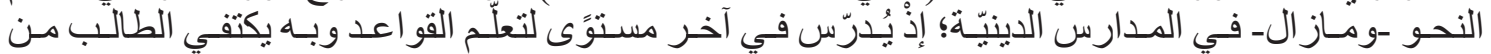

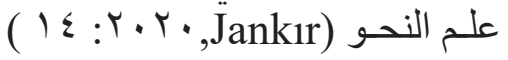

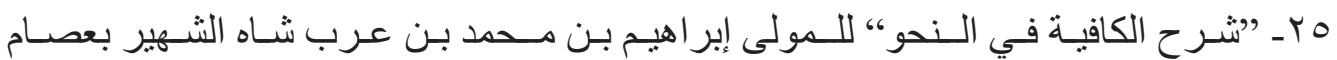

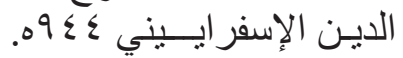

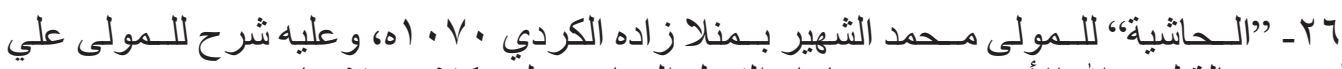

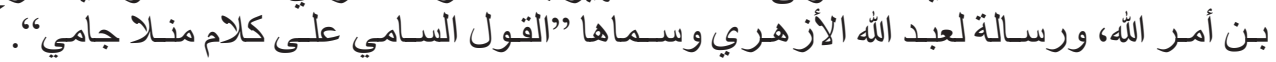

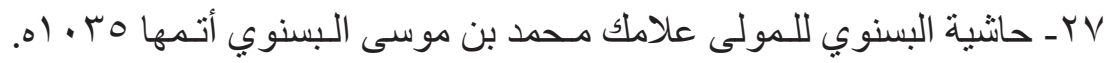

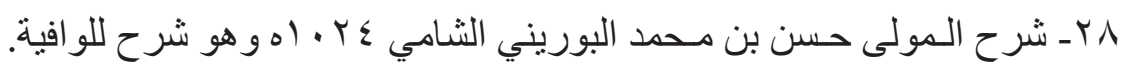

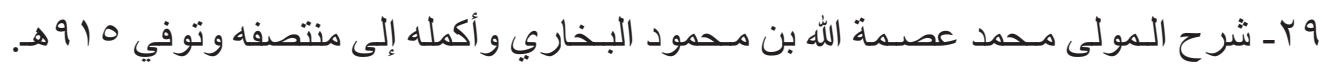

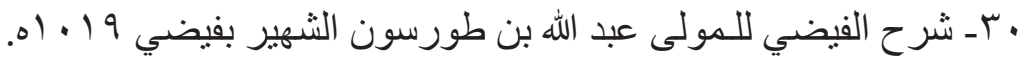

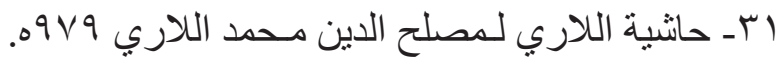

$$
\begin{aligned}
& \text { r بـ شرح السمرقندي لـشاه مـحمد بن أحمد السـمرقندي. }
\end{aligned}
$$




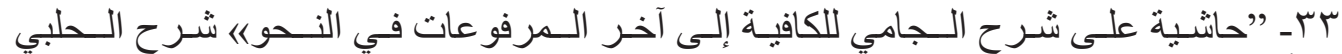

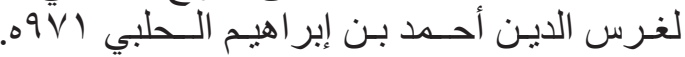

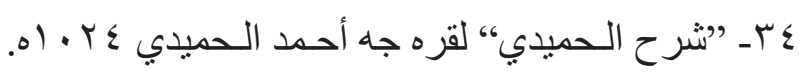

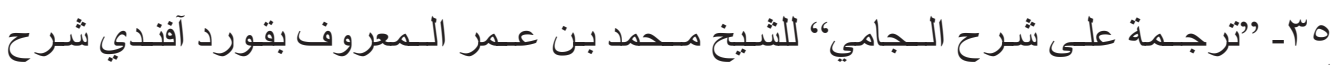
الـجامي بالتركي

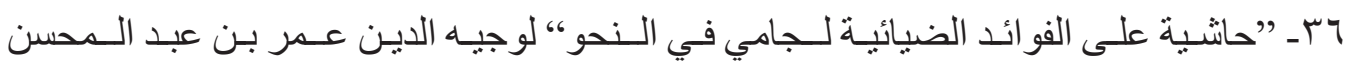

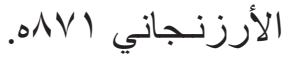

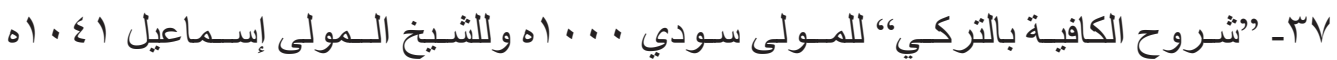

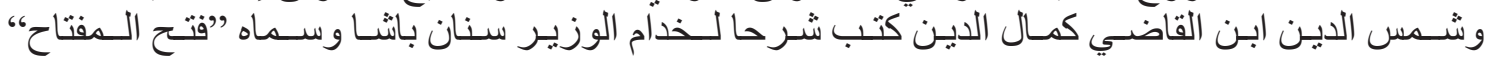

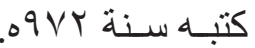

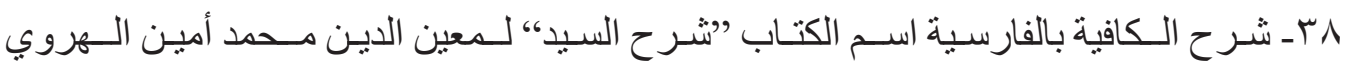
$.090 \leqslant$

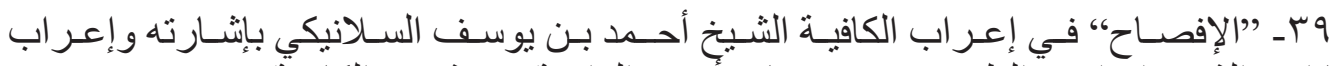

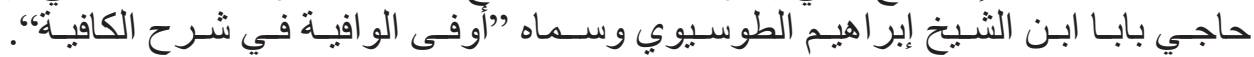

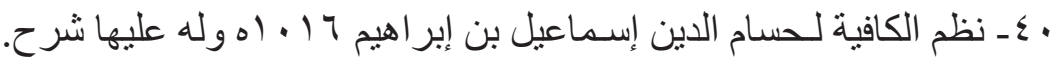

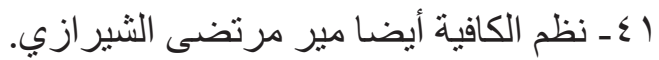

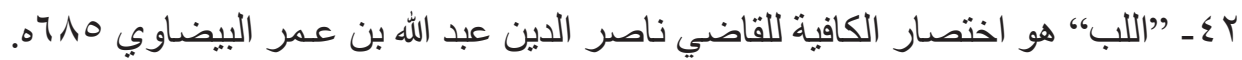

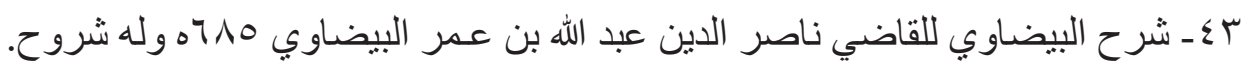

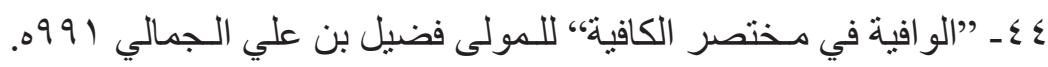

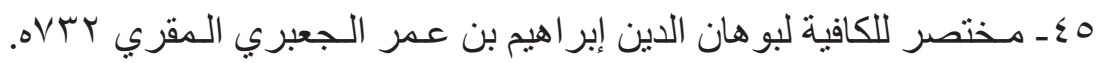
7 ـ ـ مـختصر لـحمد ابن الثيخ مـمود المغلوي الوفائي.

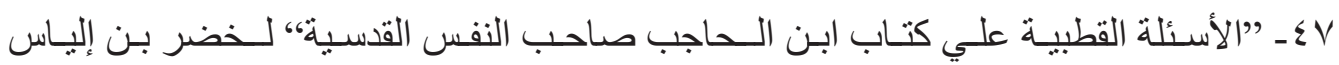
الكمولجنوي. ^ــ " "التحفة الثافية“، لبعض الـتأخرين. 9 ـ " "الدرة البيضاء“، لبعض المتأخرين.

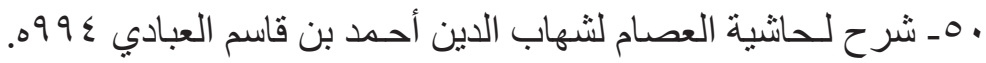

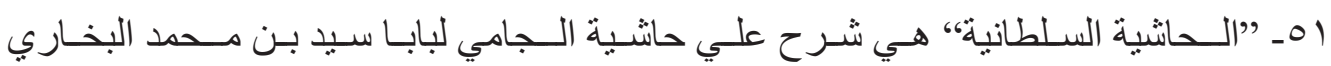
الـمعروف بباباثـاه.

ror حاثية على شرح الجامي لإبن طورسون عبد اللة الرومي • (1 - 1.

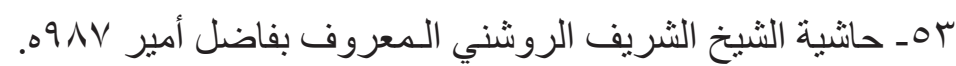

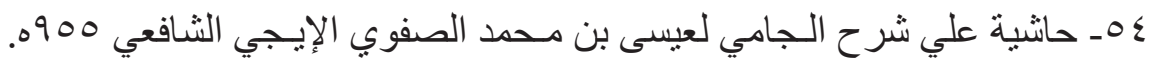

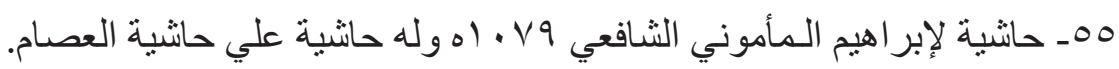
7هـ شرح الكافية لإسحاق بن مـحمد بن العـيد الملقب بكبير الدهلوي.

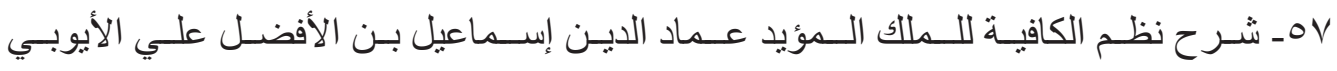




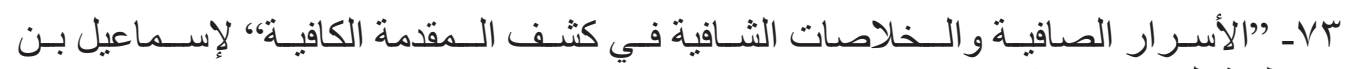

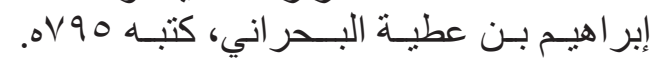

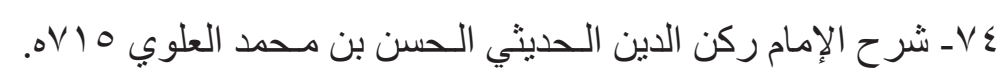

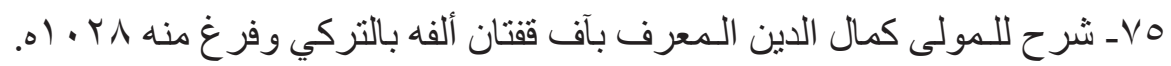

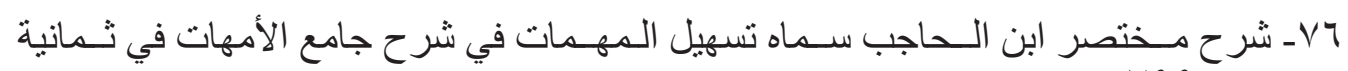

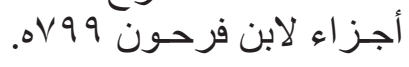
الخاتمة الغابن

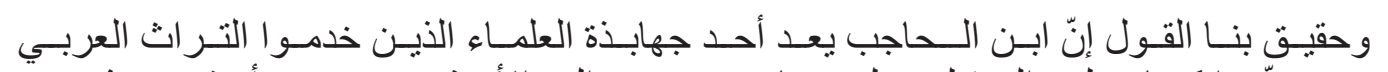

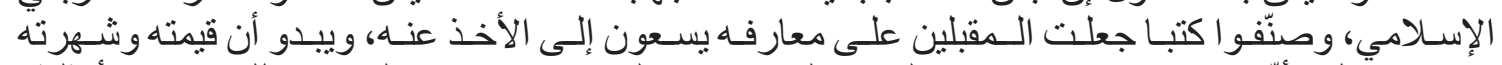

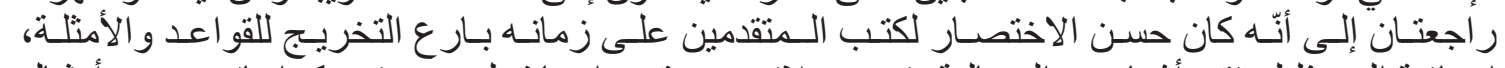

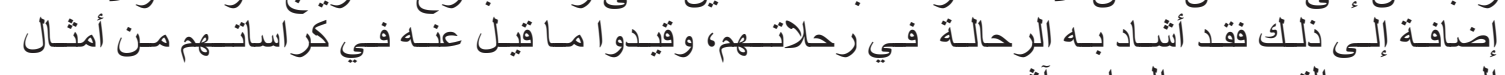

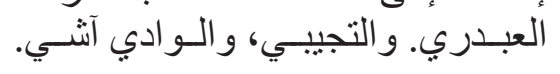
وفي الـختام بـحسن بنـا الـمقام ذكـر بيتيـن مـن نظم ابـن الــاجب نقلهمـا العبدري في رحلته و هما: إِنْ تَغَيُوُ عَنِ الْعُيونِ فأنتم 


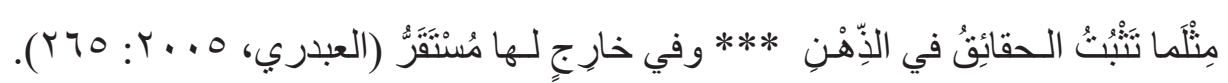

المصادر

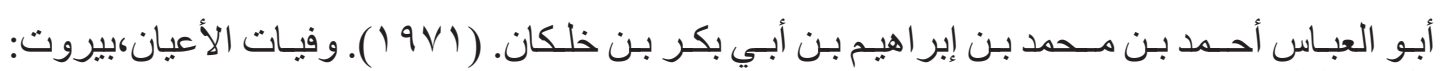

دار الكتب العلــمية.

أبـو الفـرج مــحمد بـن أبـي يعقوب إسـحاق الـمعروف بالنديــ. ( (9V1) ). الفهرسـت، بيـروت: دار

الكتب العلــمية.

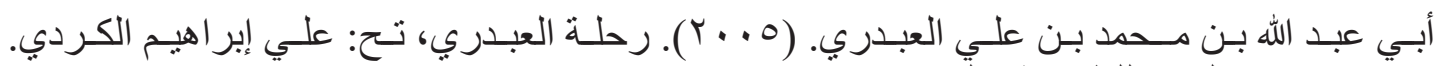

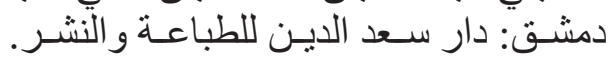

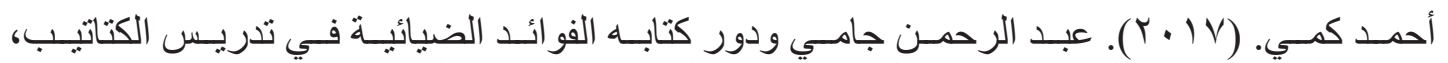

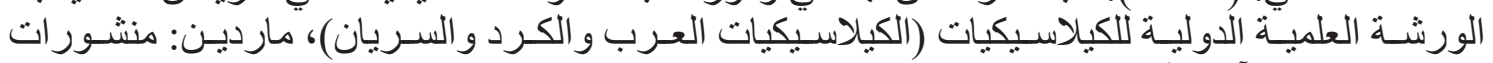

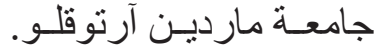

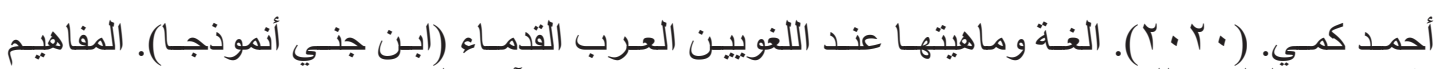

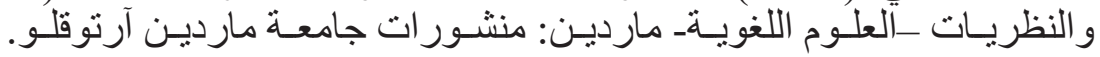

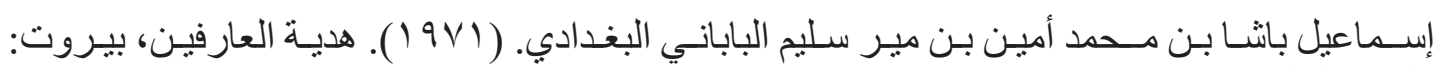
دار الكتب العلــمية.

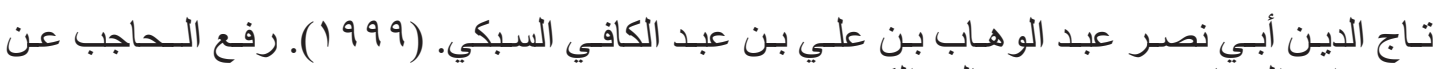
مـختصر ابن الـحاجب، بيـروت: عالـم الكتب.

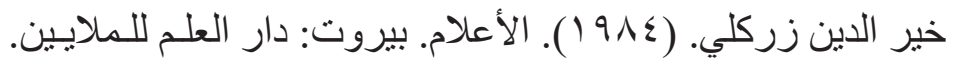

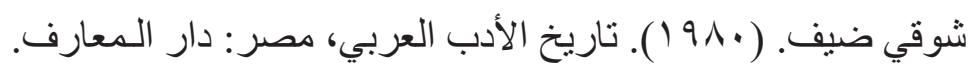

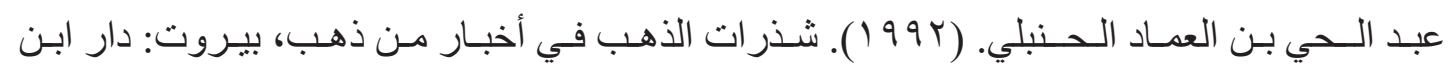

عبد الكريـم مـحد الأسعد. (ب999 (19). الوسيط في تاريخ النحو العربي، الرياض: دار الثواف. عمر رضا كحالة. (ب9 99 (). معجم الـمؤلفين، بيروت: مؤسسة الرسالة. كاتب جلبي (حاجي خليفة). ( (9V I ). كثنف الظنون، بيروت: دار الكتب العلمية.

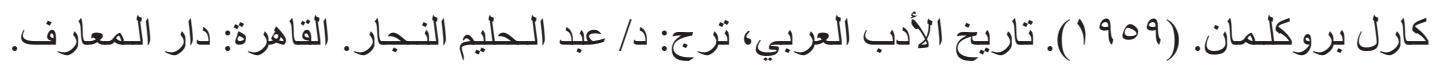

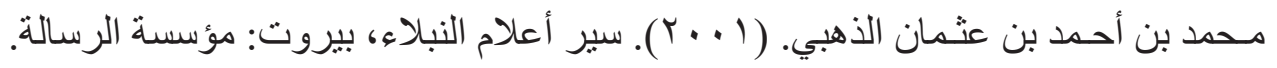

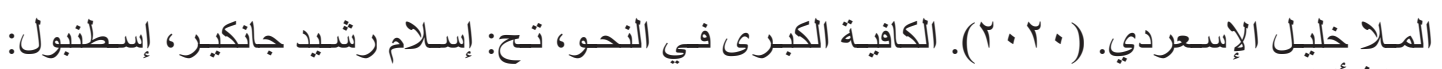
سونجاغ أكاديمي. ياقوت الحموي. ( • (91 ). معجم الأدباء، بيروت: دار الفكر. يوسف إليان سركيس. (؟). معجم المطبو عات العربية والمعربة، القاهرة: دار الثقافة الدينية.

el-Abderî, Ebî 'Abdullâh b. Muhammed b. 'Alî el-'Abderî. (2005). Rihletü'l-'Abderî. Tahkîk: 'Alî İbrâhîm el-Kurdî, Takdîm d. Şâkir el-Fahham, Dimaşk: Dâr Sa'd ed-Dîn littibâ' ve en-Neşr.

Brockelmann, Cârl. (1959). Târîhü'l-Edebi'l- 'Arabî. Terceme: Dr. ‘Abd el-Halîm en-Neccâr. Kahire: Dârü'l-Ma'ârif. 
Dayf, Şevkî. (1980). Târîhü'l-Edebi'l- 'Arabî. Mısır: Dârü'l-Ma ‘ârif.

el-Bağdâdî, İsmâ‘îl Bâşâ b. Muhammed Emîn b. Mir Selim el-Bâbânî. (1971). Hediyyetü'l- 'Ârifinn. Beyrut: Dârü'l-Kütübi'l-'ilmeyye.

el-Hamevî, Yâkût. (1980). Mu 'cem el-Udebâ. Beyrut: Dâr'ul-Fikr.

Gemi, Ahmet. (2017). “Abdürrahman Câmî ve el-Fevâidü’z-Ziyâiyye Adlı Eserinin Medrese Eğitimindeki Rolü.” Uluslararası Klasikler Çalıștayı (Arap, Kürt ve Süryani Klasikleri), (15-17 Mayıs 2017). Mardin: Mardin Artuklu Üniversitesi Yayınları.

Gemi, Ahmet. (2020). "Klasik Arap Dilcilerine Göre Dil ve Mahiyeti (İbn Cinnî Örnegi)." Kavramlar ve Kuramlar -Dil Bilimleri-. Mardin: Mardin Artuklu Üniversitesi Yayınları.

İbn Hallıkân. (1971). Ebû el-'abbâs Ahmed b. Muhammed b. İbrâhîm b. Ebî Bekir b. Hallikân, Vefeyât el-A 'yân. Beyrut: Dârü'l-Kütubi'l-ilmiyye.

İbn İmâd, 'Abdülhay b. el-'İmâd el-Hanbelî, (1992). Şezerâtü'z-Zeheb fî Ahbâr Men Zeheb. Beyrut: Dâr İbn Kesîr.

İbn Nedim. (1971). Ebû el-Ferec Muhammed b. Ebî Ya'kûb İshak. el-Fihrist. Beyrût: Dâr el-Kütub el-'İlmiyye.

Kâtib Çelebi, (Hâcî Halîfe). (1971). Keş̧ü 'z-Zünûn. Beyrut: Dârü'l-Kütübi'l-'ilmeyye.

Kehhâle, ‘Ömer Rızâ. (1993). Mu 'cemü'l-Müellifin. Beyrut: Müessesetü’r-Risâle.

Kılıç, Hulusi. (2000). “İbnü>l-Hâcib”, DİA, c. 21, İstanbul: Türkiye Diyanet Vakfi Yayınlar.

Molla Halil el-Esardî. (2020). el-Kafiyetu'l-Kubra, thk. Aslam Jankır, İstanbul: Sonçağ Yayınları.

Öztürk, Mustafa, (2013). “Zemahşerî”, DIAA, c. 44, İstanbul: Türkiye Diyanet Vakfi Yayınları.

Serkis, Yûsuf İlyân. (?). Mu'cemü'l-Matbû'âti'l-'Arabiye ve'l-Mu'riba. Kahire: Dârü’s-Sekâfeti'd-dîniyye.

es-Sübkî, Tâced-Dîn Ebî Nasr 'Abd el-Vahhâb b. 'Alî b. 'Abd el-kâfî. Ref'ül-hâcib 'an Muhtasar İbnü'l-Hâcib. Beyrut: Alemü'l-kütüb.

Yavuz, Mehmet,(1996). “İbn Cinnî Hayatı ve Arap Gramerindeki Yeri”, İstanbul: Doktora tezi.

ez-Zehebî, Muhammed b. Ahmed b. 'Osmân. (2001). Siyeru a 'lâmi’n-Nübelâ. Beyrut: Müessesetür-Risâle.

Zirikli, Hayredddîn. (1984). el-A 'lâm. Beyrut: Dârü’l-'İlm lilmelâyîn. 


\section{The Journal of Mesopotamian Studies (JMS)}

\section{Yayın İlkeleri}

Mardin Artuklu Üniversitesi Türkiye'de Yaşayan Diller Enstitüsü tarafından çıkarılan JMS (The Journal of Mesopotamian Studies), Kürt, Arap ve Süryani dili kültürü ve edebiyatları alanlarındaki bilimsel nitelikli çalıșmalara yer veren hakemli bir dergidir. Kış (Şubat) ve Yaz (Ağustos) sayıları olmak üzere yılda iki defa yayınlanır. Yayınlanacak yazılarda bilimsel araştırma ölçütlerine uygunluk, alana bir yenilik getirme ve bașka yerde yayınlanmamıș olma șartı aranır. Bilimsel bir toplantıda sunulmuș bildiriler, yayınlanmamış olmak şartıyla kabul edilebilir.

\section{Yazıların Değerlendirilmesi}

Dergimize gönderilen yazılar, öncelikli olarak yayın kurulunca dergi ilkelerine uygunluk açısından incelenir. İlkelere uygun bulunanlar, iki hakeme gönderilir. Yazarlar, hakemlerin önerilerini dikkate alıp gerekli düzeltmeleri yaparlar; fakat katılmadıkları noktalara itiraz etme hakkına sahiptirler.

Gönderilen telif makaleler, Editör Kurulu tarafından incelendikten sonra değerlendirilmek üzere "kör hakem" yöntemiyle konunun uzmanı iki hakeme gönderilir. İki hakemin görüş ayrılığı durumunda, üçüncü bir hakemin görüşüne başvurulur. Makale, en az iki hakemden olumlu rapor gelmesi halinde yayınlanır. Hakem raporları yazara gönderilerek karar bildirilir.

Hakemlerden biri veya her ikisi, "düzeltmelerden sonra yayınlanabilir" görüşü belirtirse, gerekli düzeltmelerin yapılması için makale yazara gönderilir. Düzeltme yapıldıktan sonra hakemlerin uyarılarının dikkate alınıp alınmadığı hakem veya Editör Kurulu tarafından değerlendirilir. Ayrıca yazarların, hakemler tarafından belirtilen görüşlere itiraz etme hakkı bulunmaktadır. Yapılan itirazlar editör kurulu tarafından görüşülüp uygun bir karar alınır.

Yayınlanmasına karar verilen yazılar, sayfa düzenlemesi yapıldıktan sonra pdf formatında yazarlara gönderilir. Yazar son okumayı yapar ve gerekli düzeltmeleri metin üzerinde işaretleyerek dergiye geri gönderir.

Yayınlanmayan yazılar iade edilmez ve yazılardaki görüşlerin yasal sorumluluğu yazarlarına aittir.

Yayınlanan yazılar için yazardan dergiye veya dergiden yazara herhangi bir ücret ödenmez.

Yayın aşamasında yazılar üzerinde esasa yönelik olmayan küçük düzeltmeler Editör Kurulu tarafından yapılabilir.

Yayınlanan yazıların yayın hakları MAÜ Türkiye'de Yaşayan Diller Enstitüsü’ne devredilmiş sayılır. Bu devir, sanal ortamı da kapsar.

Makale gönderimi ve değerlendirme süreci Dergipark sistemi üzerinden yürütülür.

Makaleler değerlendirme sürecine alınmadan önce iThentica intihal programı kullanılarak benzerlik analizine tabii tutulur.

\section{Yayın Dili}

JMS'nin yayın dili Türkçe, Kürtçe, Arapça, İngilizce ve Süryanicedir. Ancak her sayıda, dergide yer alan çalışmaların en az yarısının Kürtçe ve onun çeşitli lehçelerinde yazılmış olması ilke olarak benimsenmiştir. Dergiye gönderilecek yazıların akademik dil kullanımıyla ilgili her türlü kusurdan arınmış olması gerekir.

\section{Yazım Kuralları ve Sayfa Düzeni}

Yazılar A4 boyutunda kâğıda, MS Word veya uyumlu program- larla yazılmalıdır. Yazı karakteri olarak Times New Roman kullanılmalıdır. Yazılar 12 punto ve 1.5 satır aralığıyla yazılmalı, sayfalar numaralandırılmalıdır. Makalelerin uzunluğu en fazla 9.000 sözcük olmalıdır. Özel yazı karakterleri kullanılmamalı, transkripsiyon işaretleri varsa bununla ilgili dokumanlar ulaştırılmalıdır.

Yazarın adı, soyadı, unvanı, görev yaptığı kurum, ORCID numarası ve e-posta adresi mutlaka belirtilmelidir.

Makalenin başlığı içerikle uyumlu olup koyu harflerle yazılmalı ve 15 sözcüğügeçmemelidir.

Makalenin başında, en fazla 150 ile 200 sözcükten oluşan bir öz yer almalıdır. Türkçe dışındaki dillerde yazılan makalelerde öz makalenin orijinal dilinin yanı sıra Türkçe ve İngilizce olarak da yazılmalıdır. İngilizce öz kısmında makalenin ismine de yer verilmelidir. Özlerin altında genelden özele doğru sıralanmış 4 ila 6 sözcükten oluşan anahtar sözcükler bulunmalıdır.

Başlıklar koyu harflerle yazılmalıdır. Uzun yazılarda ara başlıkların kullanılması okuyucu açısından yararlıdır. Ana başlıkların, 1., 2., ara başlıklarınsa, 1.1., 1.2., 2.1., 2.2 şeklinde numaralandırılması tavsiye edilir. Ana ve ara başlıkların tümü (ana bölümler, kaynaklar ve ekler) koyu harflerle yazılmalıdır.

Metin içindeki vurgulanması gereken ifadeler, "tırnak içinde" gösterilir, eğik veya koyu karakter kullanılmaz. Hem "tırnak içinde" hem eğik veya hem koyu hem eğik yazmak gibi çifte vurgulama yapilmaz.

Bölüm ve paragraf başlarında girinti uygulanmaz.

Yazılarda kullanılan çizim, grafik, resim ve benzerimalzemeler JPEG ya da GIF formatında olmalıdır. Görsel malzeme ve ekler gerektiğinde e-posta yoluyla ayrıca ulaştırılmalıdır.

\section{Kaynak Gösterimi}

Alıntı yapma ve kaynak göstermede APA yöntemi kabul edilmektedir.

Dipnot ve kaynakların yazımı konusunda, yöntem bakımından kendi içinde tutarlılık şarttır. Uzun yapıt (kitap, dergi, gazete vb.) adları eğik, kısa yapıt (makale, öykü, şiir vb.) adları ise "tırnak içinde" yazılır. Ayrıca dipnotların yalnızca metne alınamayan ek bilgiler için kullanılması önerilir:

Bir yapıtın derleyeni, çevireni, yayına hazırlayanı, editörü varsa künyede mutlaka gösterilmelidir.

Elektronik ortamdaki metinlerin kaynak olarak gösterilmesinde, yazarı, başlığı ve yayın tarihi belirtilmiş olanlar kullanılır. Ayrıca künye bilgilerinde parantez içinde erişim tarihi belirtilmelidir.

Ulaşılabilir kaynaklarda ikincil kaynak kullanımından kaçını1malıdir.

Atıf yapılmayan çalışmalara Kaynaklar kısmında kesinlikle yer verilmemelidir.

Kaynaklar metnin sonunda, yazarların soyadına göre alfabetik olarak yazılmalıdır. Eserlerin yayınevleri açık șekilde ve makalelerin bulunduğu sayfa aralıkları belirtilmelidir.

Latin harfleri dışındaki alfabelerle yazılmış makalelerde Latin harfleriyle yazılmış başlık, özet, anahtar kelimeler, ve kaynakçaya (referanslar) yer verilmelidir. 